NBER WORKING PAPER SERIES

\title{
LOCAL DOES AS LOCAL IS: \\ INFORMATION CONTENT OF THE GEOGRAPHY \\ OF INDIVIDUAL INVESTORS' \\ COMMON STOCK INVESTMENTS
}

\author{
Zoran Ivkovich \\ Scott Weisbenner \\ Working Paper 9685 \\ http://www.nber.org/papers/w9685 \\ NATIONAL BUREAU OF ECONOMIC RESEARCH \\ 1050 Massachusetts Avenue \\ Cambridge, MA 02138 \\ May 2003
}

Both authors are from the Department of Finance, University of Illinois at Urbana-Champaign. Scott Weisbenner is with the NBER. We would like to extend our gratitude to an anonymous retail discount broker for providing the data on individual investors. positions, trades, and demographics. Special thanks go to Terry Odean for his help in obtaining and understanding the data set. We thank Alok Kumar for useful insights and helpful discussions. Both authors acknowledge the financial support from the College Research Board at the University of Illinois at Urbana-Champaign. Finally, we thank seminar participants at the University of Illinois for their comments and constructive suggestions. All remaining errors are the sole responsibility of the authors. The views expressed herein are those of the authors and not necessarily those of the National Bureau of Economic Research.

(O2003 by Zoran Ivkovich and Scott Weisbenner. All rights reserved. Short sections of text not to exceed two paragraphs, may be quoted without explicit permission provided that full credit including $O$ notice, is given to the source. 
Local Does as Local Is: Information Content of the Geography of

Individual Investors' Common Stock Investments

Zoran Ivkovich and Scott Weisbenner

NBER Working Paper No. 9685

May 2003

JEL No. G11, G14

\begin{abstract}
Using a data set on the investments made by a large number of retail investors from 1991 to 1996 , we find that households exhibit a strong preference for local investment-the average household invests nearly a third of their portfolio in firms headquartered within 250 miles. We test whether this locality bias is driven by information or by simple familiarity. The average household generates an additional return of $3.7 \%$ per year from its local holdings relative to its non-local holdings, suggesting local investors are able to exploit local knowledge. The excess return to investing locally is even larger among stocks not in the S\&P 500 index (firms where informational asymmetries between local and non-local investors may be largest), while there is no excess return earned by households that invest in local S\&P 500 stocks.
\end{abstract}

Zoran Ivkovich

Department of Finance

University of Illinois

340 Wohlers Hall

1206 South Sixth Street

Champaign, IL 61820

ivkovich@uiuc.edu
Scott Weisbenner

Department of Finance

University of Illinois

304C David Kinley Hall, MC-706

1407 W. Gregory Drive

Urbana, IL 61801

and NBER

weisbenn@uiuc.edu 


\title{
Local Does as Local Is: Information Content of the Geography of Individual Investors' Common Stock Investments
}

\begin{abstract}
Using a data set on the investments made by a large number of retail investors from 1991 to 1996, we find that households exhibit a strong preference for local investment - the average household invests nearly a third of their portfolio in firms headquartered within 250 miles. We test whether this locality bias is driven by information or by simple familiarity. The average household generates an additional return of $3.7 \%$ per year from its local holdings relative to its non-local holdings, suggesting local investors are able to exploit local knowledge. The excess return to investing locally is even larger among stocks not in the S\&P 500 index (firms where informational asymmetries between local and non-local investors may be largest), while there is no excess return earned by households that invest in local S\&P 500 stocks.
\end{abstract}

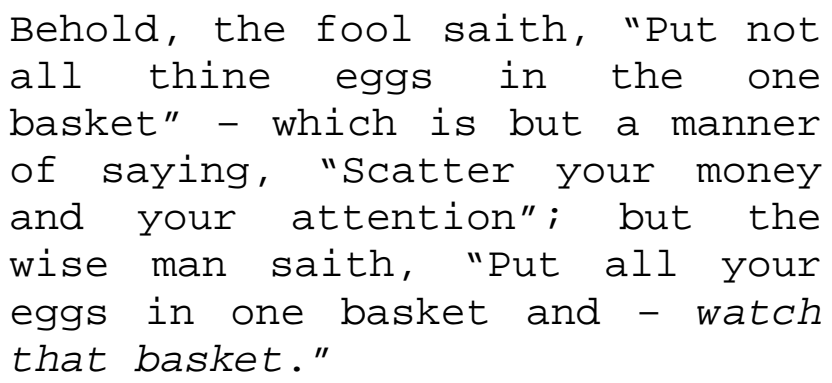

Mark Twain 1894

The finance literature has yielded a large number of in-depth studies concerning the investments managed by professional money managers, yet, historically, relatively little has been known about individual investors' money management, in no small part because of the shortage of highquality data available for academic research. This, despite the fact that U.S. individual investors have been holding around $50 \%$ of the stock market in direct stock investments.

The key issue we address in this paper is the availability of asymmetric information in financial markets, particularly in the context of geography of investment by individual investors. While it is well understood that there may be a number of determinants of the availability and 
quality of information about a company, including, for example, company size, number of analysts following it, and the media coverage, it is reasonable to hypothesize that, ceteris paribus, investors may be able to gather value-relevant information about companies local to them (henceforth local companies) with greater ease and accuracy than they could about remote companies (henceforth non-local companies). Indeed, Coval and Moskowitz (2001) demonstrate that professional managers' local investments outperform their remote investments, a finding that both provides a richer characterization of professional managers' skill and, more importantly in the context of this paper, suggests that proximity to investment opportunities facilitates the acquisition of disproportionately accurate value-relevant information.

Using a detailed data set on the investments 78,000 U.S. retail investors made through a large discount broker over the six-year period from 1991 to $1996,{ }^{\square}$ we find that individual investors exhibit local bias, that is, disproportionate preference for local stocks, to an even larger degree than U.S. mutual fund managers do (see Coval and Moskowitz, 1999). 1 We find that the average share of local investments (defined as the investments into companies headquartered within 250 miles from the investor) is around 30\%, both in terms of the number of stocks in the household portfolio and their value. This figure is disproportionately high - nearly 20 percentage points higher than the average percent of all firms headquartered within 250 miles from the household (both equally and value-weighted).

While it appears that the professional managers' preferences for, and especially success in, pursuing local investment opportunities stem from their ability to exploit the ensuing information asymmetries (Coval and Moskowitz, 2001), it is not clear whether the individual investors' local bias is primarily a result of their ability to exploit asymmetric information or their inclination simply to invest into the companies they are familiar with (though not necessarily particularly informed about).

That households would have a disproportionate preference for local stocks is not unexpected. There is evidence that people tend disproportionately to invest in the companies they are relatively familiar with, be it by virtue of their inclination to favor domestic investments over

\footnotetext{
${ }^{1}$ To protect the confidentiality and anonymity of investor data and the retail broker, all researchers using the data set must sign and adhere to an appropriate non-disclosure agreement.

${ }^{2}$ For existing studies of individual investors' investment see, e.g., Barber and Odean (2000, 2001), Dhar and Kumar (2001), Dhar and Zhu (2002), Goetzmann and Kumar (2002), Hong and Kumar (2002), Kumar (2002), and Zhu (2002).
} 
investments in foreign assets - the so-called home bias, or, in the domestic arena, invest disproportionately into own-company stock (Benartzi (2001) and Liang \& Weisbenner (2002)). If individual investors' local investments stem primarily from non-information based reasons, as the evidence presented in Huberman (2001), Grinblatt and Kelohraju (2001), and Zhu (2002) suggests, then investors' locality should be interpreted primarily as a behavioral phenomenon. If locality stems from household investing into the companies they are familiar with, though not necessarily particularly informed about, local investments will likely not earn superior returns on average. Indeed, Benartzi (2001) finds in the context of 401(k) plans that allocations to company stock, the most local of all investments, does not predict future returns.

On the other hand, if the individual investors' local bias is information-driven, we should uncover evidence of superiority of their local investments, at least relative to their non-local investments. Such a finding would shed some light not only on the individual investors' ability to identify and exploit informational asymmetries, but also on the interpretation of the professional managers' investment skill. Indeed, if individual investors could generate superior returns on their local investments, then such an accomplishment by professional managers would seem less impressive and should be reinterpreted primarily as the skill first to realize that there is investment value in uncovering local information and then to collect it, rather than the skill to carry out particularly insightful analyses of such information.

The central question we address is whether local investments are based on value-relevant information, in which case those investments should do well on average, or whether they stem primarily from households investing into the companies they are familiar with, though not necessarily particularly informed about, in which case the local investments will likely not earn superior returns on average. Thus, we next address the relation between location-driven information asymmetry and household portfolio returns. Simply put, if individual investors succeed in collecting and processing locally available value-relevant information, then the value of that information should be reflected in the performance of their household portfolios.

In our initial inquiry, we find that local investments outperformed non-local ones by $3.7 \%$ per year over a one-year horizon. The excess return to investing locally is even larger among stocks not in the S\&P 500 index (firms where informational asymmetries between local

\footnotetext{
${ }^{3}$ For key results related to home bias see, e.g., French and Poterba (1991), Cooper and Kaplanis (1994), Gehrig (1993), and Tesar and Werner (1997).
} 
and non-local investors may be largest), while there is no excess return earned by households that invest in local S\&P 500 stocks (where informational asymmetries are likely smallest). Moreover, the evidence is robust to the choice of the period of returns measurement, various adjustments for risk, the industry composition of the portfolio, the location of the household, as well as alternative explanations such as insider trading on own/former employers' stock.

Having established that household portfolio performance is positively related with the extent and nature of locality in investors' portfolios and that the bulk of the performance differential stems from the investments in less widely known (non-S\&P 500) stocks, we explore the benefits of pursuing locality by mimicking households' local investments and shying away from their non-local investments. To that end, we first dissect common stocks in each household portfolio according to two dimensions, locality of the stocks and their S\&P 500 status (our proxy for information asymmetry), and then form aggregate position-weighted portfolios across all households. The results support the hypothesis that locally available information is valuerelevant. Specifically, the zero-cost portfolio that takes a long position in local investments and a short position in non-local investments has statistically and economically significant returns: monthly raw (risk-adjusted) returns are 19 (12) basis points. This effect stems primarily from the stocks that exhibit more information asymmetry. Indeed, the corresponding raw returns and riskadjusted returns are substantially smaller for S\&P 500 stocks (12 and 8 basis points per month, respectively) than for non-S\&P 500 stocks ( 27 and 26 basis points per month, respectively). These results are striking, as the only portfolio formation criteria were related to the geography and a basic stock index membership characteristic. Even these simple breakdowns yielded abnormal performance of $3.2-3.3 \%$ per year, and adjustment for risk characteristics of the portfolios made virtually no difference.

The final question we address is whether the effect of locally available value-relevant information can be compensated for by simply observing a firm's local ownership, that is, the collective opinion of the potential investors local to the firm. In other words, if the investor is not local, should he join the locals (i.e., follow the actions of the investors local to the firm)? The results suggest that merely favoring non-local non-S\&P 500 stocks with high local ownership goes a long way toward reducing and almost eliminating the information asymmetry between the local and non-local non-S\&P 500 stocks. Simply put, mimicking what locals do is about as good as being local. 
The remainder of this paper is organized as follows. Section I presents the data and summary statistics. Section II considers the characteristics and determinants of locality of investment from the perspective of the household. Section III focuses on the determinants of firm relative local ownership. Section IV seeks to characterize and quantify the information asymmetry related to locality of investment and provides a number of robustness checks. Finally, Section V concludes.

\section{Data and Descriptive Statistics}

\section{I.A. Data}

We compile the data for this paper from several sources. The primary source is a large data set, obtained from a retail brokerage house, of individual investors' monthly positions and trades over a six-year period from 1991 to 1996. The data set covers all the investments 78,000 households made through the brokerage house, ranging from common stocks, mutual funds, government and corporate bonds, foreign securities, to derivatives. Each household could have as few as one account and as many as 21 accounts (the median is 2). The data set also provides some information about the households, such as their zip code, self-reported income, occupation, and age. For a detailed description of the data set see Barber and Odean (2000).

In this paper we focus on the common stocks traded on the NYSE, AMEX, and NASDAQ exchanges. Common stock investments constitute nearly $2 / 3$ of the total value of household investments in the sample. We use the Center for Research in Security Prices (CRSP) database to obtain information on stock prices and returns and COMPUSTAT to obtain several

firm characteristics, including company headquarters location (identified by its state and county codes). We use the headquarters location as opposed to the state of incorporation because firms often do not have the majority of their operations in their state of incorporation.

The sample of households used in this study is a subset of the entire collection of households for which we could ascertain their zip code and thus determine their location. We identify around 11,300 distinct zip codes in the data. We exclude from the sample households that were not located in the continental U.S. (that is, investors from Hawaii, Alaska, and Puerto Rico) and several zip codes corresponding to military installations. We obtained the latitude and longitude for each of the zip codes from the U.S. Census Bureau's Gazetteer Place and Zip Code Database. The corresponding company location comes from COMPUSTAT Annual Research 
Files, which contain the information regarding the company headquarters' county code. Finally, we identify the latitude and longitude for each county from the U.S. Census Bureau's Gazetteer Place and Zip Code Database as well. We use the standard formula for computing the distance $\mathrm{d}(\mathrm{a}, \mathrm{b})$ in statutory miles between two points $\mathrm{a}$ and $\mathrm{b}$ as follows:

$\mathrm{d}(\mathrm{a}, \mathrm{b})=\arccos \left\{\cos \left(\mathrm{a}_{1}\right) \cos \left(\mathrm{b}_{1}\right) \cos \left(\mathrm{a}_{2}\right) \cos \left(\mathrm{b}_{2}\right)+\cos \left(\mathrm{a}_{1}\right) \sin \left(\mathrm{b}_{1}\right) \cos \left(\mathrm{a}_{2}\right) \sin \left(\mathrm{b}_{2}\right)+\sin \left(\mathrm{a}_{1}\right) \sin \left(\mathrm{a}_{2}\right)\right\} \frac{\pi}{180} r$,

where $a_{1}$ and $b_{1}\left(a_{2}\right.$ and $b_{2}$ )are the latitudes (longitudes) of points $a$ and $b$ (expressed in degrees), respectively, and $r$ denotes the radius of the Earth (approximately 3,963 statutory miles).

We exclude the stocks we could not match with CRSP and COMPUSTAT; they were most likely listed on smaller exchanges. We also exclude stocks not headquartered in the continental U.S. The resulting "market" - the universe of stocks we could obtain the necessary characteristics and information about - consists of 4,827 stocks at the end of 1991, which cover $76 \%$ of the overall market capitalization at the end of 1991.

In each sample year, we discard the households with the total portfolio value under $\$ 1,000$ as of the end of the previous year. In sum, the resulting sample of households holding at least one common stock that we could identify and characterize in at least one of their account portfolios consists of 31,828 households at the end of 1991. This number tends to change somewhat over the sample period, reflecting primarily the liquidation of some accounts (the trades in the last month sell off the positions at the end of the previous month and there are no subsequent positions or trades recorded for the account).

\section{I.B. Descriptive Statistics}

Basic household sample characteristics are presented in Table I. The table reports summary statistics of household income and household portfolio statistics at the end of 1991. 7 Panel A presents the income statistics. Households could report income in nine ranges (0-15, 15-20, 20-30, 30-40, 40-50, 50-75, 75-100, 100-125, and 125+ thousands of dollars per year). One eighth of the households (13\%) did not provide income information. We assume that the income level for the households in the first eight categories was the midpoint of the income range. Based on calculations using the 1992 Survey of Consumer Finances (SCF), the average 
household income in 1991 for households that had at least $\$ 125,000$ of income was $\$ 250,000$ (see Kennickell and Starr-McCluer (1994) for a description of the SCF data set). Thus, we assign the income level of $\$ 250,000$ to the households that reported income greater than $\$ 125,000$. The median household that actually reported its annual income reported income in the range from $\$ 50,000$ to $\$ 75,000$ (the midpoint presented in the table is $\$ 63$ thousand) and the interquartile range of income range midpoints is $\$ 45-\$ 113$ thousand. Thus, households in the sample are clearly more affluent than the average household in the U.S.

Panel B focuses on households portfolios of NYSE, AMEX, and NASDAQ common stocks as documented by the position files at the end of 1991. The mean value of common stocks in household portfolios was $\$ 29,643$, while the median was $\$ 11,201$. The average household held relatively few stocks (on average 3.0 stocks; the median was only 2 stocks per household). Around 38\% of the households in the sample held assets other than common stocks (most often mutual funds). Among such households, around one-third of the average household portfolio was allocated to assets other than common stocks (35\% average; $29 \%$ median). Thus, the commonstock portions of household portfolios in the sample typically consisted of a handful of stocks, which precludes the possibility of extensive diversification among common stocks. ${ }^{\mathrm{B}}$ We focus on these three household portfolio characteristics and on household income because we view them as (admittedly noisy) measures of two important facets of investment: propensity toward diversification (larger number of stocks, presence of asset classes other than common stocks) and availability of resources to collect information (larger dollar value of the portfolio and household income).

Table I, Panel C further summarizes household portfolio statistics pertaining to the locality of their common stock investments according to two metrics. The first is a simple comparison of the distance from the household to its portfolio and the distance from the household to the market portfolio (the upper three rows in the panel). The second metric employs household proximity to company headquarters, where we set the threshold of locality at the distance of 250 miles (the lower three rows in the panel). Household portfolio distance measures

\footnotetext{
${ }^{4}$ Portfolio summary statistics for subsequent years (not reported) are qualitatively similar to those presented in Table I. Details are available upon request.

${ }^{5}$ While diversification could be more pronounced for the households holding other asset classes, the summary statistics suggest that nearly $2 / 3$ of all households in the sample (62\%) held only (typically very few) common stocks and were thus largely undiversified. Moreover, Goetzmann and Kumar (2002) show that the investors' portfolios were under-diversified relative to the extent of diversification possible when holding few stocks.
} 
were computed by value-weighting the distance measures across individual stocks in the portfolio according to their household portfolio equity position.

Panel C of Table I provides evidence of considerable local bias. The average (median) portfolio is closer to the household than the market by about 300 miles. Put differently, average (median) households were closer to their portfolios than to the market portfolio by around $23 \%$, although the nontrivial interquartile range suggests a broad range of locality, from households substantially closer to their portfolio than to the market (by around 700 miles or more) to those that are somewhat further away from their portfolio than to the market (by around 150 miles or more).

These figures, though illustrative, do not necessarily treat investors in an equitable fashion, as investors in New York, for example, that hold the market portfolio would turn out to be far more local than investors in North Dakota that hold the same portfolio. In most subsequent analyses, we use a more intuitive and less biased approach. We regard 250 miles as a plausible upper bound on the span of local information and regard all investments into companies whose headquarters are within that distance as local. The distance of 250 miles is still reachable via a moderately strenuous daily roundtrip by car; local newspapers, radio, TV, and other media still occasionally provide some coverage of the local events within that distance. This cutoff is admittedly arbitrary and it could be argued that it is on the conservative side. ${ }^{6}$ Nevertheless, we identify strong locality effects that match economic intuition based on information asymmetry.

In the sample of households at the end of 1991 the mean (median) percentage of the number of stocks in the household portfolio headquartered within 250 miles from the investor is $30.7 \%(0 \%)$. In fact, slightly less than one-half of the households $(15,458$ of 31,828$)$ invest in at least one local firm. The interquartile range further suggests that at least $25 \%$ of the households in the sample have more local than non-local stocks in their portfolios (the actual number is $32 \%$ ), a statistic that could be driven in part by the geographic distribution of investors and companies. As shown in Figure 1, New York and California boast disproportionately high numbers of both. We control for the geographic distribution of companies relative to investors by subtracting from this percentage another percentage - the fraction of all firms within 250 miles (presented in the fifth row of Table I, Panel C). The resulting measure of household locality, call

\footnotetext{
${ }^{6}$ As a robustness check, we replicate the key analyses with the locality cutoff set at 100 kilometers (see Section $I V . H)$ and the results are even stronger, which suggests that our choice of 250 miles as the cutoff is conservative.
} 
it $\mathrm{H}_{\mathrm{LOC}, \mathrm{w}}$, is summarized in the last row of Table I, Panel C. It is similar to the simple distribution of the percentage of portfolio stocks within 250 miles. The mean percentage of local firms that households invest into exceeds the percentage of all local firms by $18.1 \%$ on average.

Before proceeding, we provide an illustration of the properties of $\mathrm{H}_{\mathrm{LOC}, \mathrm{w}}$. Its range is from $-42 \%$ to $99.95 \%$ at the end of 1991 . The first (low) extreme is typical of the households that chose to invest only non-locally, yet live in the area with many local investment opportunities (large percentage of the total market). A prominent example is a completely nonlocal investor living in New York City or Silicon Valley. The other extreme is typical of investors living in remote areas where there are very few local investment opportunities (and all are very small companies), yet their entire household portfolios are invested locally.

\section{Household Locality}

\section{II.A. Household Locality Characteristics}

Table II explores household portfolio locality in still more detail. The first column reports the distribution of household investments by locality that would prevail if investors invested in the most obvious benchmark - the market portfolio. As an alternative, given that the investors are not well-diversified (the mean number of stocks in a household's portfolio from our sample is three), in column (2) we also consider a different benchmark. ${ }^{0}$ The portfolio shares listed for this benchmark represent the hypothetical locality breakdown if instead of holding its individual stocks each household invested in the appropriate value-weighted industry portfolio corresponding to each of its individual stocks. "The "If invested in Industry Portfolio" shares in column (2) represent the hypothetical locality breakdown wherein for each stock the measure of locality is the ratio of aggregate market capitalization of all local firms belonging to the same industry and aggregate market capitalization all firms nationwide belonging to the same industry, and all the individual stock measures are then aggregated according to the weights of the respective stocks in the household portfolio. The next five columns, columns (3) - (7), present shares of portfolio value for all households, as well as the subsamples selected according to

\footnotetext{
${ }^{7}$ We thank the referee for suggesting this robustness check.

${ }^{8}$ Firms are assigned to one of the following 14 industry groups based on SIC code: mining, oil and gas, construction, food, basic materials, medical/biotech, manufacturing, transportation, telecommunications, utilities, retail/wholesale trade, finance, technology, and services. Using either the equally-weighted industry portfolio corresponding to each stock or a randomly-selected firm in the same industry as the benchmark yield very similar results.
} 
certain characteristics. Finally, the last column presents the fraction of households that invest only into one of the categories listed in the rows of the table in both panels.

The first three columns illustrate how the portfolio shares deviate from the shares that would be found if every household invested in the market portfolio or the appropriate industry portfolio. For example, the average household invests $31 \%$ of its portfolio locally; however, the local share would be only $13 \%$ if each household invested in the market or the appropriate industry portfolio. Thus, relative to either benchmark, individuals' portfolios are subject to pronounced a local bias. The bulk of this local bias can be attributed to investments in local nonS\&P 500 stocks. These stocks constitute on average 15\% of the household portfolio, but would only make up $3 \%$ if the household invested in the market. Households also tend to place disproportionately more weight on local S\&P 500 stocks (16\% in actual portfolio versus $9 \%$ in the market portfolio on average), while placing substantially less weight on non-local S\&P 500 stocks (41\% in actual portfolio versus $61 \%$ in the market portfolio on average). Finally, the average household portfolio share allocated to S\&P 500 stocks is 57\%, 14\% less than the share if investing in the market portfolio. Intuitively, it is this $14 \%$ under-weighting of the S\&P 500 that allows for the $12 \%$ over-weighting of non-local non-S\&P 500 stocks in the average household portfolio.

These tendencies may be related to information asymmetry. Simply put, there are likely companies about which there is more information than the others. Potential determinants of such information asymmetry could include the overall size of the company (measured by market capitalization, number of employees, number of plants, etc.), the number of analysts following the stock, and membership in a major stock index. For example, the potential for sizeable information asymmetry is considerably smaller for S\&P 500 than for non-S\&P 500 companies. Thus, it is likely that information asymmetry is the most pronounced in the case of non-local vs. local investment into non-S\&P 500 companies. Intuitively, investments into local S\&P 500 stocks are unlikely to be driven by the hope to exploit value-relevant information available only to local individual investors. The third column of Table II suggests individual investors' portfolios exhibit greater disproportion between S\&P 500 and non-S\&P 500 non-local investments than between local ones. Across all households, 3/5 of non-local investments are in S\&P 500 companies on average, while roughly half of local investments are in S\&P 500 firms. 
Thus, investors tend to favor the remote familiarity of non-local S\&P 500 stocks over the uncertainty of non-local non-S\&P 500 stocks.

The next four columns of Table II, columns (4) - (7), test for robustness of the basic breakdown; they feature virtually identical breakdowns for all households exclusive of CA, CA households, as well as households with portfolio values of at least $\$ 10,000$ and at least $\$ 50,000$, respectively. Focusing on households from California, who constitute just over one quarter of the sample, is done to confirm that locality in investments is not driven by these CA households. The extent of locality of households with larger portfolios is an empirical issue. It could be higher than for smaller portfolios because larger portfolios signal the availability of resources to investigate and uncover value-relevant local information. On the other hand, it could be lower because larger portfolios are likely to consist of more stocks and also be combined with investments other than common stocks, both of which are suggestive of tendencies to achieve better diversification. As it turns out, with the increase in portfolio value the presence in local non-S\&P 500 stocks is gradually substituted with non-local S\&P 500 stocks.

Finally, the last column of Table II illustrates that many households are either all local (one-sixth) or all non-local (one-half). This is not too surprising, given the small number of stocks in the average household portfolio. About one out of every twelve households only hold non-S\&P 500 firms headquartered within 250 miles.

\section{II.B. Household Locality Determinants}

Table III presents the results of fitting cross-sectional regressions of four household portfolio (HHP) locality measures, computed at the end of 1991 and summarized in Table I, ${ }^{\natural}$ on several explanatory variables as follows:

HHP Locality $=\alpha+\beta_{1} \log ($ Number of stocks in HHP $)+\beta_{2} \log ($ Value of stocks in HHP $)+$ $\beta_{3} \log ($ Household income $)+\beta_{4}$ Did not report income +

$\beta_{5}$ Hold other assets

Each specification is fitted in both the OLS and the fixed-effects regression frameworks. The intent of the fixed-effect regression, carried out at the zip-code level, is to control for

\footnotetext{
${ }^{9}$ Results based on year-end measures of locality and explanatory variables for the remaining years in the sample (1992 through 1995) are qualitatively similar. Results are available from authors upon request.
} 
potential biases in the geographic distribution of households and firms in the sample. The first two measures are based on the average distance from the household to its portfolio and thus are negatively related to household portfolio locality. By contrast, the other two measures are based on the fraction of portfolio value within 250 miles from the household and are each positively related to household portfolio locality.

Consistently across all specification, variables Log(Number of stocksinHHP) and Hold other assets are statistically significant and are both negatively related to HHP Locality. This finding is intuitive, as it suggests that a larger extent of diversification translates into a smaller extent of household portfolio locality. On the other hand, $\log$ (Value of stocks in HHP) is also statistically significant across all specifications, but is positively related to locality. $\log ($ Household income) is also positively related with locality, although it lacks statistical significance, especially in the fixed effects regressions. Both Log(Value of stocks in HHP) and $\log$ (Household income) are indicative of the availability of resources and expertise in information acquisition, which appears to be more efficient in the domain of local stocks, thus resulting in increasing household portfolio locality.

\section{Firm-Level Locality}

In this section we focus on the determinants of local stock ownership. We define $R L O_{j, t}$, the firm relative local ownership for firm $j$ at the end of year $t$, as follows:

$$
R L O_{j, t}=\frac{\$ o w n_{j, t}^{L(j)}}{\$ o w n_{j, t}^{L(j)}+\$ o w n_{j, t}^{N L(j)}}-\frac{\sum_{k} \$ o w n_{k, t}^{L(k)}}{\sum_{k} \$ o w n_{k, t}^{L(k)}+\sum_{k} \$ o w n_{k, t}^{N L(k)}},
$$

where $\$ o w n_{j, t}^{L(j)}$ and $\$ o w n_{j, t}^{N L(j)}$ denote the total value of the position in stock $j$ by the households that had household portfolios of at least $\$ 1,000$ and were local and non-local to firm $j$, respectively. As before, the threshold for locality is set to 250 miles. To eliminate the noise stemming from thin ownership in the sample, we include in the following analyses only the firms held by at least five investors in year $t$. Relative local ownership, $R L O_{j, t}$, is defined as the fraction of household stock ownership in the firm held by households located within 250 miles of the firm (the first fraction) less the fraction of total nation-wide household portfolio wealth held by households located within 250 miles of the firm (the second fraction). 
A key result from Section II is that households on average invest disproportionately into local firms. In this section we consider the dual question of what characterizes firm relative local ownership. To that end, we form a panel of all firm-year observations in the sample and regress firm relative local ownership on several firm characteristics. The panel structure of the data prompts us to account for the unobserved year effects by adding year dummy variables into the specification and to allow for the correlation of the firm-specific error terms across time.

Table IV presents regression results for all firms, S\&P 500 firms, and non-S\&P 500 firms. Aside from the regression approach outlined above (denoted as "Mean"), we also report the results of a robust median regression estimator (denoted as "Median"). Regressions fitted for all firms highlight that firm relative local ownership is related negatively to leverage, positively to the number of employees, and negatively to the firm's S\&P 500 membership status, while it is largely unrelated to market value ${ }^{10}$ From the perspective of information asymmetry, we interpret the number of employees as a noisy proxy of the opportunity to collect value-relevant information locally, or perhaps to simply become aware of the firm's existence (familiarity), which is gained through social interactions with the employees (i.e., word-of-mouth).

There is also an alternative explanation for the positive effect of the number of employees on relative local ownership. Other studies have documented the effects of an underlying strong preference for company stock or equities, showing that those who hold a high proportion of equities in pension savings also hold a high fraction of non-pension assets in equities (Bodie and Crane (1997) and Weisbenner (2002)), and that employees for firms that require the company match contributions to the $401(\mathrm{k})$ plan to be invested in company stock tend to invest more of their own 401(k) contributions in company stock (Benartzi (2001) and Liang \& Weisbenner (2002)). If employees of firms tend to invest part of their non-pension plan wealth in company stock, this could also explain why local ownership is higher for firms with more employees.

However, these issues are unlikely to drive locality in the sample. The majority of the accounts in the database are non-retirement accounts. The accounts that are retirement accounts are either Individual Retirement Accounts (IRAs) or Keough plans, none are retirement plans sponsored by an investor's current employer. Thus, if a household is investing in its employer's

\footnotetext{
${ }^{10}$ In unreported analyses, we compare the distributions of market value of local and non-local investments and find that they are very similar. This robustness check alleviates the possible concern that local investments are made into micro-cap stocks to a larger extent than non-local investments and that many of the results reported in the paper may
} 
stock through its $401(\mathrm{k})$ plan, this will not be contained in our data. The only investment in the stock of a company household members currently work for that would be reflected in our data would be investments in non-401(k) accounts. However, if a household member left an employer that offered a 401(k) plan, then the balance of that plan could have been rolled over into an IRA. Thus, while retirement account holdings in our data will not contain stock of the current employer, they may contain stock of a former employer.

While a key vehicle for own-firm stock ownership, 401(k) plans, is not included in our data, households' potential ownership of a previous employer's stock through an IRA, or employees investing in their current firm's stock in non-retirement accounts potentially could cloud the conclusions drawn from our subsequent analyses, as the extent of locality and the returns based on locality might stem primarily from trading on inside information. 11 To address this concern, in Sections $I V . B$ and $I V . F$ we conduct appropriate robustness checks.

We regard the S\&P 500 status as a fairly accurate measure of both familiarity and the extent of availability of private, value-relevant information that would be more easily accessible to local investors. Simply put, S\&P 500 companies are followed by many stock analysts, owned and researched by many institutional investors, held by numerous S\&P 500 index funds and other mutual funds, and closely followed by the financial press and other media. Implications of such popularity of S\&P 500 stocks are twofold. First, there generally is disproportionately little value-relevant private information regarding S\&P 500 stocks to begin with and locality is unlikely to help (being from Seattle does not likely give a substantial advantage in acquiring information about Microsoft). Second, it does not require locality to be familiar with S\&P 500 stocks. Thus, it is not surprising that the loading on the S\&P 500 status is significantly negative.

Moreover, the regressions fitted for S\&P 500 firms did not yield any statistically significant determinants whose significance would be consistent across the two regressions (mean and median). It thus appears that relative local ownership of S\&P 500 firms is not strongly related to firm characteristics. On the other hand, regressions fitted only for non-S\&P 500 firms result in the statistical significance, same direction, and comparable magnitude of the impact of leverage and number of employees. This confirms the intuition that non-S\&P 500 firms were the primary drivers of the results from Table IV for all firms.

stem from the extraordinary performance of micro-cap stocks in the sample period. We thank Josef Lakonishok for pointing out this issue. 


\section{Information Asymmetry and Locality: Performance and Investment Implications}

This section examines the relation between location-driven information asymmetry and household portfolio returns. We seek to quantify the value of locally available information via a simple proposition that if individual investors succeed in collecting and processing locally available value-relevant information, then the value of that information should be reflected in the performance of their household portfolios.

\section{IV.A. A First Look}

The initial point of inquiry is the relation between household portfolio performance and the allocation of household portfolio weights to local and non-local investments. We first regress raw household portfolio returns $R_{t, t+k}^{H H P}$ over $k$-year horizons $(k=1,2, \ldots, 5)$ on the household portfolio weights of local and non-local investment ( $\% L_{t}$ and $\% N L_{t}$, respectively) at the end of year $t$ :

$$
R_{t, t+k}^{H H P}=\beta_{L} \% L_{t}+\beta_{N L} \% N L_{t} .
$$

As before, we control for potential biases in the geographic distribution of households and firms in the sample via the zip-code level fixed-effect regression. The results of fitting regressions based on year $t=1991$ are presented in the first six columns of Table V, Panel A. The difference between the regression coefficients on the shares of local and non-local investments (the highlighted row in the panel) suggests that local investments outperformed non-local ones by $3.7 \%$ (4.8\% with zip-code level fixed effects) per year on the one-year horizon. 12 Intuitively, investors who invested $x \%$ into local stocks would have outperformed entirely non-local investors by $3.7 \cdot x \%(4.8 \cdot x \%)$ per year on average.

As argued earlier, there likely is disproportionately little value-relevant private information regarding S\&P 500 stocks to begin with and locality is unlikely to help (being from Seattle does not likely give a substantial advantage in acquiring information about Microsoft).

\footnotetext{
${ }^{11}$ We thank the referee for raising this concern and for suggesting a means of addressing it.

${ }^{12}$ Local investment outperformed non-local ones by $4.7 \%$ ( $9.2 \%$ with fixed effects) over the 3 -year horizon and by $15.8 \%$ (25.0\% with fixed effects) over the 5-year horizon.
} 
To capture the notion that there should be more information asymmetry between local and nonlocal investors in non-S\&P 500 stocks as opposed to local and non-local investors in widely followed and researched S\&P 500 stocks, we also estimate the following regression:

$$
R_{t, t+k}^{H H P}=\beta_{L, S P} \% L_{S P, t}+\beta_{N L, S P} \% N L_{S P, t}+\beta_{L, N S P} \% L_{N S P, t}+\beta_{N L, N S P} \% N L_{N S P, t},
$$

where $\% L_{S P, t}$ and $\% N L_{S P, t}\left(\% L_{N S P, t}\right.$ and $\left.\% N L_{N S P, t}\right)$ denote household portfolio weights on local and non-local S\&P 500 (non-S\&P 500) stocks, respectively. Our hypothesis is that the differential in returns between local vs. non-local investments should be more pronounced for non-S\&P 500 stocks, and perhaps even non-existent for S\&P 500 stocks. The results are presented in the first six columns of Table V, Panel B. The difference between the regression coefficients on the shares of S\&P 500 local and non-local investments (the first highlighted row in the panel) suggests that local investments outperformed non-local ones by $1.5 \%$ (3.5\% with zip-code level fixed effects) per year on the one-year horizon, whereas the differences on longer horizons were not statistically different from zero. By contrast, the difference between the regression coefficients on the shares of non-S\&P 500 local and non-local investments is substantially higher, that is, $6.1 \%$ (5.9\% with zip-code level fixed effects) per year on the oneyear horizon and, generally, this gap grows with the investment horizon. ${ }^{3}$ The third highlighted row in the panel features the difference between the two differences - this reflects the return to locality in non-S\&P 500 companies relative to S\&P 500 companies. Its interpretation is the extent to which the premium in investing locally increases with the increase in information asymmetry, in this case $4.5 \%$ per year $(2.4 \%$ with fixed effects) on the one-year horizon and progressively more for longer investment horizons. Though statistical significance of this difference is sometimes dampened with the introduction of zip-code fixed effects, the results presented in this table are compelling.

These analyses included all the households that held at least $\$ 1,000$ in their portfolio at the end of 1991. We test whether larger household portfolios (portfolio values of at least $\$ 10,000$ or $\$ 50,000$ at the end of 1991) drive the results from Panels A and B because portfolio value may be correlated with the availability of resources and skill in uncovering locality information. The

\footnotetext{
${ }^{13}$ Local investment into non-S\&P 500 stocks outperformed S\&P 500 non-local ones by $11.0 \%$ (15.5\% with fixed effects) over the 3-year horizon and by $36.3 \%$ (53.8\% with fixed effects) over the 5-year horizon.
} 
results, not reported for brevity, largely show that the effect is only somewhat stronger for larger portfolios. 14

To address the concern that the choice of the end of 1991 as the portfolio formation date could have driven the results, we replicate the above analyses for portfolio formation dates in other sample years - at the end of 1992, 1993, 1994, and 1995-for return horizons ranging from one year up to five years (as permitted by the end of the sample period). Another facet of this robustness check is fitting both the mean estimator (OLS) and the robust median regression estimator. In unreported analyses we find that the results are very robust along both dimensions: for both mean (OLS) and median estimators, the reported difference between differences estimators are mostly statistically significant, similar in magnitude at a given return horizon, and increasing monotonically with the return horizon.

Another concern we address is the potential relation between the locality of investment and portfolio risk. For example, if local investments were concentrated in small technology stocks, then raw returns for local investments would exceed those for non-local investments on average. However, the additional return would reflect a difference in risk (small technology stocks are a riskier investment and thus should generate a higher return), as opposed to reflecting the return to the acquisition of local information. For each household we compute the average risk-adjusted monthly return by fitting time-series regressions of excess household portfolio returns on four factors (three Fama-French factors and the momentum factor):

$$
R_{t}^{H H P}-R_{f, t}=\alpha^{H H P}+\beta_{1} R M R F_{t}+\beta_{2} S M B_{t}+\beta_{3} H M L_{t}+\beta_{4} M O M_{t}+\varepsilon_{t}^{H H P} .
$$

We estimate risk-adjusted household portfolio performance $\alpha^{H H P}$ for all the households in the sample that had at least 36 monthly returns during the five-year sample period and then regress these estimates (expressed in basis points per month) on the locality breakdown as before:

\footnotetext{
${ }^{14}$ We further checked whether the relation between locality and returns could be driven by omitted household characteristics that were shown in Table III to be associated with local investing (such as portfolio value and whether the household holds non-common stock assets in the portfolio). For example, perhaps higher household wealth could serve as a proxy for the availability of resources and skill to uncover value-relevant local information, and thus its inclusion in the return regression would render the locality effects insignificant. In unreported analyses we found the estimated effects of locality to be unchanged with the inclusion of household characteristics such as the size of portfolio.
} 


$$
\begin{aligned}
& \alpha^{H H P}=\beta_{L} \% L+\beta_{N L} \% N L \quad \text { and } \\
& \alpha^{H H P}=\beta_{L, S P} \% L_{S P}+\beta_{N L, S P} \% N L_{S P}+\beta_{L, N S P} \% L_{N S P}+\beta_{N L, N S P} \% N L_{N S P} .
\end{aligned}
$$

The results, presented in the last two columns of Table V, are quite striking: after controlling for risk, across every specification the best performing investments are local non-S\&P 500 stocks and the worst performing investments are non-local non-S\&P 500 stocks. Two key statistics in Panel B - the difference between the regression coefficients on the shares of non-S\&P 500 local and non-local investments and the difference between differences estimators (the last two highlighted rows in the table) - suggest that the effect of the information asymmetry of non-S\&P 500 local and non-local investments in the base specification (without fixed-effects) is statistically and economically significant: 25.5 basis points per month for household portfolios that held at least $\$ 1,000$ at the end of $1991^{105}$ In terms of magnitude, this coefficient, when annualized, is comparable to those based on raw returns. The difference between the differences, which quantifies the incremental advantage attainable by local investment between S\&P 500 and non-S\&P 500 stocks, is 27.1 basis points per month for household portfolios that held at least $\$ 1,000$ at the end of $1991 . \frac{16}{16}$ This coefficient is again comparable to those based on raw returns. For example, 27.1 basis points per month translates approximately $3.25 \%$ per year, whereas the corresponding annual return backed out from raw returns ranges from $3.6 \%$ to $6.6 \%$. Moreover, risk-adjusted resulted are more robust to the zip-code fixed effects. In sum, adjustment for risk did not affect the main conclusions derived from the earlier analyses based on raw returns.

\section{IV.B. Robustness Checks}

Given the time period and the geographic distribution of investors (see Figure 1), a potential concern is that the results may be influenced by certain localities and the success of certain industries. For example, around one-quarter of the households in our sample are from California.

\footnotetext{
${ }^{15}$ The coefficients resulting from the fixed-effects regression differ substantially from the regression without fixedeffects only for portfolios holding at least $\$ 50,000$, for which the coefficient is larger in magnitude, but not statistically significant. Note, however, that there are typically only one or two households with portfolios in excess of $\$ 50,000$ per zip code, thus reducing the ability to identify more precisely the returns to locality in a fixed-effects regression.

${ }^{16}$ Once again, the coefficients resulting from the fixed-effects regression differ substantially from the regression without fixed-effects only for portfolios holding at least $\$ 50,000$, for which the coefficient is both larger in magnitude (120 basis points versus 71$)$ and marginally statistically significant.
} 
For the California investors, their local investments could have been in technology companies, which tended to earn superior returns over the sample period. A first look suggests that this fact is unlikely to drive our results. Indeed, Table II suggests that the portions of portfolios invested locally for California and non-California households were virtually identical. Moreover, the inclusion of the household zip code fixed effects in our previous regressions provided control for potential biases in the geographic distribution of households and firms in the sample. Specifically, in the fixed-effects regressions the return to locality was estimated on the basis of the differences in portfolio returns within zip codes (rather than the average differences in returns across the zip codes).

The importance of this issue merits additional robustness checks. Table VI explores the relation between household portfolio monthly excess returns and locality. For brevity, in Panel A we report the difference between local and non-local investments, while in Panel B we report the difference between local and non-local S\&P 500 investments, the difference between local and non-local non-S\&P 500 investments, and the difference between the two differences. The first column displays results from the regression of average excess monthly returns on the share of the portfolio invested locally, thus replicating the results from the second to last column in Table V. The second column displays the results when the share of the portfolio allocated across 14 industry groups is also included in the regression. After controlling for the industry composition of the portfolio, the difference between the non-S\&P 500 local and non-local investments is 19.8 basis points per month, compared to the estimate of 25.5 without this control. The difference between the differences, which quantifies the incremental advantage attainable by local investments between S\&P 500 and non-S\&P 500 stocks, also falls only slightly, from 27.1 to 23.0 basis points, when portfolio industry shares are also included in the regression. This provides compelling evidence that the locality performance results are not driven by particular industries, as the return to locality is still sizeable after controlling for industry composition of the portfolio.

The next four columns test whether the return to locality is driven by California households. Focusing on the non-California households first, the difference between the nonS\&P 500 local and non-local investments is 19.7 basis points per month (19.6 when controlling for the industry composition of household portfolios). For California households, the difference between non-S\&P 500 local and non-local investments is 38.6 basis points per month, 
substantially larger than that for households elsewhere. This is not that surprising, as at the end of 1991 the average California portfolio was tilted 27.8\% towards technology stocks, compared to $19.2 \%$ for households outside of California. However, once we control for the industry composition of the portfolio, the difference between non-S\&P 500 local and non-local investments falls to 17.0 basis points per month, in line with our estimates for investors in the rest of the country.

The final two columns display results when households that had retirement accounts (IRA or Keough plans) are excluded from the sample. This analysis taps into the issue of insider information. Specifically, since households could be holding stock from a previous employer in a retirement account, assuming the 401(k) plan of the former employer was rolled over into an IRA, the locality of the household's investments could be attributed to holding the former employer's stock. In this were the case, the interpretation of the return to locality could be clouded because it could reflect insider information. Excluding the households with retirement accounts, however, does not diminish the returns to locality; if anything, they are slightly enhanced.

Table VII provides further evidence on whether the return to locality is driven by particular geographic locations of the investors. We break the sample into nine regions, as defined by the U.S. Bureau of the Census (ten regions if we separate California from the Pacific region). For each region, we estimate regressions of both one-year raw returns and average monthly excess returns and report the difference between the local and non-local investments, as well as the difference between the local and non-local investments in non-S\&P 500 stocks. The results are strikingly consistent across regions. Focusing on the first column, the difference between local and non-local investments ranges from a low of -3.6 in the West North Central region, to 12.4 in the West South Central region. Six of the nine regions have significantly positive returns to investing locally, while none of the three negative point estimates are significant. For eight of the nine regions, local non-S\&P 500 investments outperform non-local non-S\&P 500 investments, with the difference statistically significant in five. The differential in one-year returns exceeds $15 \%$ in the East South Central, the West South Central, and New England. A similar pattern emerges when we focus on excess returns: local investments outperform non-local investments in a majority of the regions, and often significantly so. 
Throughout the sample period, households enter and leave the sample. Of the 31,828 households with at least $\$ 1,000$ in stock holdings at the end of 1991, around one third of the households reported an equity position in November 1996. Other households either appear in the sample after a certain number of months or disappear from the sample by liquidating their positions and closing the account. Thus, in a given period we get to observe the performance of a household if it "survives," that is, does not get liquidated. A potential concern at this point might be survivorship bias (see, e.g., Brown, Goetzmann, Ibbotson, Ingersoll, and Ross (1992)). Indeed, in the domain of performance measurement of professional money managers, survivorship bias is a concern because money managers who disappear from the sample have often been underperformers, and their absence from the sample biases performance measures upward. In our sample, we find no evidence that individual investors systematically liquidated their positions because of their underperformance.

The final concern is that the portfolio breakdown with respect to locality, that is, the weights $\% L_{S P}, \% N L_{S P}, \% L_{N S P}$, and $\% N L_{N S P}$, are computed at the beginning of the returns measurement period. Although in unreported analyses we find that household locality is a highly persistent phenomenon, household portfolio locality may change over time, and relying on the portfolio locality breakdown at the beginning of the return measurement period introduces noise that may worsen as the returns period increases. While this consideration may have some bearing on the precision of the estimates pertaining to longer horizons, the one-year measures of information advantages of locality are unlikely to be substantially affected by the potentially stale portfolio locality breakdown. Moreover, it is not clear how to avoid stale information in this context, as regressing returns on some type of average portfolio locality breakdown computed during the return measurement period would raise concerns about endogeneity. We alleviate this

\footnotetext{
${ }^{17}$ To test whether the liquidation of accounts was related to household portfolio performance, we calculated the portfolio returns of both the households that remained in the sample until the end (November 1996) and those who liquidated their account before the end of the sample. There were 24,901 households that appeared in the regression relating the locality of their portfolio at the end of 1991 to portfolio returns in 1992. Of these households, the 5,582 that maintained stock ownership in their accounts continuously through November 1996 had an average portfolio return of $10.9 \%$ in 1992. The remaining 19,319 households that liquidated their account some time before the end of the sample had an average portfolio return of $11.5 \%$ in 1992. Furthermore, there were 21,719 households for which average monthly excess (risk-adjusted) returns were calculated and related to household locality. The average excess monthly return for the households that maintained stock ownership in their accounts continuously through November 1996 was 10.8 basis points, compared to 13.7 basis points for the households that liquidated their account some time before the end of the sample. Finally, in unreported analyses, we regressed the probability of a household liquidating their account during the year to the household's prior one-year portfolio return separately for each year.
} 
concern in the subsequent analyses by forming portfolios that include a number of households with a certain profile of local investment and rebalance such portfolios annually.

\section{IV.C. Pursuing Locality: The Portfolio Perspective}

The previous section suggests that household portfolio performance is positively related with the extent and nature of locality in investors' portfolios and that the bulk of the performance differential stems from the investments in less widely known (non-S\&P 500) stocks. In this and the next three sections we seek to quantify the economic value of local investment. We begin with a simple question: what are the benefits of pursuing locality by simply following the household portfolios aggregated according to varying degrees of their locality of investment.

At the beginning of each year (end of January for 1991), households are ranked based on the locality of their portfolio relative to the market portfolio (fraction of household portfolio within 250 miles less fraction of market portfolio within 250 miles) and then assigned to locality quartiles. Average household relative locality cutoffs across all years are: $-6.7 \%$ for quartile one, $-0.8 \%$ for the second quartile, and $45.8 \%$ for the third quartile. The return for each quartile represents the weighted return for all the households in that quartile (the weight is the value of each household's portfolio). Thus, these four locality portfolios are rebalanced at the beginning of each year based on households' locality relative to the market portfolio. The sample period is from February of 1991 to December of 1996.

Table VIII summarizes the returns to the four portfolios ranked by household portfolio locality. Panel A presents average monthly raw returns and Panel B presents risk-adjusted returns, computed as excess monthly returns from the same four-factor model we used in the previous section (see Equation (6)). For both raw returns and risk-adjusted returns, the bottom three household locality quartile portfolios have similar performances and only the top quartile portfolio stands out. The performance differential relative to the top quartile, highlighted in the second column of each panel, is 19-25 basis points per month for raw returns and 15-18 basis

In no year was there a significantly negative relation between the prior portfolio return and the probability of liquidating the account. In sum, we do not uncover evidence that poor household return led to account liquidation.

${ }^{18}$ Aside from gauging the value of locality via a very simple portfolio strategy, these results, as well as those in the sections to follow, raise an interesting regulatory issue. Namely, while this and other portfolio strategies that follow are not feasible for most participants in financial markets because the information necessary to implement them is not available in a timely fashion, the discount broker handling the accounts itself has had full disclosure of all the positions and trades available in real time and the implementation of all the portfolios presented herein in principle 
points for risk-adjusted returns. This translates into the top household locality quartile outperforming the remaining three portfolios by 35-43\% (28-33\%) during the sample period according to raw (risk-adjusted) portfolio returns presented in the table. The evidence across both panels not only stresses the performance superiority of the portfolio of most local households, but also shows that this performance differential is largely not due to differences in risk exposures across portfolios.

\section{IV.D. Pursuing Locality: Dissecting Portfolios by Locality}

The analyses from the previous section relied on a simple portfolio strategy that gauged the broad impact of locality on household portfolio performance. In this section we proceed a step further by first dissecting each household portfolio according to two dimensions, locality of the investments and their S\&P 500 status (our proxy for information asymmetry), and form six aggregate position-weighted portfolios across all households.

The results are presented in Table IX. The first section of the table (left three columns) is based on the portfolios characterized only by the locality of the securities relative to the households that held them, whereas the next two sections recognize not only locality, but also the S\&P 500 status. Each section features the performance of portfolios of local and non-local stocks, drawn from the appropriate universe of stocks (all, S\&P 500, and non-S\&P 500), as well as the key portfolio of interest - the zero-cost portfolio formed by taking the long position in the portfolio of local stocks and the short position on the non-local stocks.

The results support the hypothesis that locally available information is value-relevant. Specifically, the zero-cost portfolio based on all stocks has statistically and economically significant returns: monthly raw returns are 19 basis points (12 basis points after adjusting for risk). The next two sections of Table IX further demonstrate that this effect stems primarily from the stocks that exhibit more information asymmetry. Indeed, the corresponding raw returns and risk-adjusted returns in the next two sections are very different: they are substantially smaller for S\&P 500 stocks, which most likely do not feature significant information asymmetries by investors' location, whereas they are considerably larger (27 and 26 basis points per month,

would have been a straightforward exercise. It is not immediately clear whether, setting aside the ethical issues, mimicking the portfolios in such broad, aggregate fashion is in violation of any applicable securities regulations.

${ }^{19}$ Our approach is similar in spirit to that followed by Coval and Moskowitz (2001). 
respectively) precisely where information asymmetries come into play - in the domain of nonS\&P 500 stocks.

These results are striking, as the only portfolio formation criteria we used were related to the geography and a basic stock index membership characteristic. Even these simple breakdowns yielded abnormal performance of 3.2-3.3\% per year, and adjustment for risk characteristics of the portfolios made virtually no difference.

\section{IV.E. Pursuing Locality: Combining the Two Perspectives}

The results from the previous section, compelling in their own right, do not take into account the fact that some households had very few local investments, whereas others had around one-half of their portfolio value invested in local stocks. In Section IV.C we found that households that invest locally tend to outperform the rest, although we did not determine the source of their relative success. In this section we advance our analyses a step further by bringing the two inquiries together.

The question at hand is simple: were the investors who invested more locally better able to uncover and exploit locally available value-relevant information than the investors who invested less locally. To address it, we split each of the six portfolios formed in the previous section into two subportfolios. The first (second) portfolio consists of all the portfolio positions held by households ranked below (above) the median of household locality distribution.

The results of the same analyses we carried out in Section IV.D on the twelve portfolios we form here are presented in Table X. At the top of the table we reproduce the key statistics highlighted near the bottom of Table IX, namely the raw and risk-adjusted average monthly returns for the zero-cost portfolios formed by taking the long (short) position in the respective local (non-local) portfolio. The next two rows summarize the analogous returns for the portfolios based on the positions held by non-local (below median) and local (above median) households. The results show that the ability to detect and exploit locally available value-relevant information is concentrated among the households whose portfolios tended to be more local. In each of the six columns, the second row, based on below-median locality households, features zero-cost portfolio average returns indistinguishable from zero.

\footnotetext{
${ }^{20}$ As documented in Section IV.C , he top quartile of households with respect to locality has at least $45.8 \%$ of their portfolio value invested locally.

${ }^{21}$ The average household relative locality median cutoff across all years is $-0.8 \%$.
} 
By contrast, zero-cost portfolio average returns in the third row, based on above-median locality households, in almost all cases are positive and both statistically and economically significant. In particular, the last two columns that pertain to the zero-cost portfolios most affected by the existence of locally available value-relevant information-those formed on the basis of non-S\&P 500 stocks - showcase the highest average monthly returns: $0.38 \%$ for raw returns and $0.30 \%$ for risk-adjusted returns.

These figures can be interpreted from the perspective of seeking to exploit the information contained in the investors' positions: paying attention not only to the stock characteristics, but also to the extent of household locality can enhance average zero-cost portfolio raw (abnormal) returns from $0.27 \%(0.26 \%)$ to $0.38 \%(0.30 \%)$. Moreover, this improvement, though moderate, is attainable without any incremental cost except for screening by household locality.

\section{IV.F. Further Robustness Checks}

Tables XI and XII provide additional evidence of the robustness of our results. Recall that a key vehicle for own-firm stock ownership, 401(k) plans, is not included in our data. A household's potential ownership of a previous employer's stock through an IRA or an employee investing in their current firm's stock in non-retirement accounts, however, could cloud our conclusions, as the results could be driven by the (former) employees trading on inside information. To address this concern, in Section $I V . B$ we excluded households with retirement accounts and found that such exclusion did not affect our results. In Table XI, we explore the performance of a household's largest local investment relative to its other, if any, local investments. The motivation for this analysis is intuitive: if the household were holding its ownemployer's stock, it would likely be its largest holding. ${ }^{22}$ Thus, if households purchase their own firm's stock based on inside information, the return on the portfolio of these biggest local investments, aggregated across households, should outperform the aggregated portfolio of all of the other local holdings across households.

\footnotetext{
${ }^{22}$ We thank the referee for this suggestion and for proposing the related tests.

${ }^{23}$ On average, households hold three stocks, one of which is the stock of a local company. Thus, it is not surprising that the household's biggest local investment, which may be its only local stock, comprises on average $27.4 \%$ of a household's portfolio at the end of 1991, compared to $3.3 \%$ for the other local investments.
} 
Across all stocks, across S\&P 500 stocks only, as well as across non-S\&P 500 stocks only, we cannot reject the hypothesis that there is no difference in performance between a household's largest local investment and its other local investments. This is true both of raw and risk-adjusted returns. Also, in unreported analyses, we find that, consistent with Table IX, the difference in returns in the zero-cost portfolio that takes a long position in the local investments exclusive of the biggest local investment and a short position in the non-local investments offers a significantly positive return, a finding that is even stronger when the portfolios contain only non-S\&P 500 investments. In sum, these results provide compelling evidence that the performance of households' local investments is not driven by insider trading, as there is no difference in the performance of the largest local holding relative to other local investments.

Table XII provides further evidence on the return to locality for California households relative to investors elsewhere, augmenting the results in Tables VI \& VII. Focusing on non-S\&P 500 investments, we seek to establish whether the 26 basis points per month excess return to the non-S\&P 500 zero-cost portfolio (long local and short non-local), shown in Table IX, is driven by California investors. Both risk-adjusted performance and raw returns to the zero-cost strategies suggest that California investors did not outperform non-California ones. If anything, both measures seem to be larger for non-California investors.

As a final robustness check we separated investments in technology and medical/biotechnology stocks, two good performers during our sample period, from all other investments, and tested whether the superior performance of local investments held for both groups of investments. At the end of 1991, technology/medical stocks comprised on average $35.4 \%$ of the household portfolio. We found that, focusing on non-S\&P 500 investments, the return of the zero-cost portfolio (aggregated across all households) that takes a long-position in local tech/medical stocks and a short position in non-local tech/medical stocks was 35 basis points per month $(\mathrm{p}=0.080)$, while the return on the analogous zero-cost portfolio that excludes tech/medical stocks was 26 basis points per month $(\mathrm{p}=0.019)$. The difference is not statistically different from zero $(p=0.705) .{ }^{24}$ This analysis complements the finding in Table VI that the return to locality persists after controlling for the industry composition of the portfolio.

\footnotetext{
${ }^{24}$ Details are available from authors upon request.
} 


\section{IV.G. Pursuing Locality: Follow the Locals}

As an indirect test of the value of locally available value-relevant information, we examine more closely the performance of the non-local non-S\&P 500 part of a household's portfolio. NonS\&P 500 stocks that are distant to the household are the stocks that a household is likely at the greatest informational disadvantage relative to local investors. Suppose one considers investing in the stock of a remote, non-local firm. Further suppose that there is locally available valuerelevant information about the firm. If it turns out that the locals invest heavily in this stock, chances are the stock will perform well. On the other hand, if locals (who likely have an informational advantage on the prospects of the firm, particularly for non-S\&P 500 companies) shy away from the stock, chances are the performance will be lackluster. ${ }^{25}$ Thus, if equipped with the knowledge of a remote stock's relative local ownership, a non-local investor might be able to reap the benefits of the local investors' due diligence. To capture the relative local ownership effect, we employ the regression analyses used in Section IV.A. Table XIII presents the results of fitting the following regressions:

$$
\begin{aligned}
& R_{t, t+k}^{H H P}=\beta_{1} \% L_{S P, t}+\beta_{2} \% N L_{S P, t}+\beta_{3} \% L_{N S P, t}+\beta_{4} \% N L_{N S P, t}^{H i g h R O}+\beta_{5} \% N L_{N S P, t}^{\text {LowRLO }} \text { and } \\
& \alpha^{H H P}=\beta_{1} \% L_{S P}+\beta_{2} \% N L_{S P}+\beta_{3} \% L_{N S P}+\beta_{4} \% N L_{N S P}^{H i g h R L O}+\beta_{5} \% N L_{N S P}^{\text {LowRLO }},
\end{aligned}
$$

where, as before, $\% L_{S P, t}$ and $\% N L_{S P, t}\left(\% L_{N S P, t}\right.$ and $\left.\% N L_{N S P, t}\right)$ denote household portfolio weights on local and non-local S\&P 500 (non-S\&P 500) stocks, respectively. In this specification, the latter is further split according to relative local ownership into $\% N L_{N S P, t}^{H i g h R O}$ and $\% N L$ LOwPLO

Regardless of the returns horizon or risk-adjustment, the hypothesis that all coefficients on non-S\&P 500 stocks are the same is readily rejected. At the same time, the difference between local non-S\&P 500 stocks and high relative local ownership non-local non-S\&P 500 is very small for raw returns on the one-year horizon (1.1\%), increasing moderately for longer horizons

\footnotetext{
${ }^{25}$ There is a direct analogy to selecting a non-franchise restaurant when one travels. Chances are if locals happen to frequent the establishment you select, one will be satisfied with the meal. On the other hand, if locals avoid the restaurant one selects, the dining experience will likely be less than satisfactory.

${ }^{26}$ On average, non-S\&P 500 non-local stocks constitute $28.2 \%$ of the value of a household's portfolio (14.2\% has high RLO, 14.0 has low RLO).
} 
and at best of marginal statistical significance. The risk-adjusted return of 12 basis points per month translates into approximately $1.5 \%$ per year. Thus, merely favoring non-local non-S\&P 500 stocks with high relative local ownership goes a long way toward reducing and almost eliminating the information asymmetry between the local and non-local non-S\&P 500 stocks. The second highlighted row presents the difference between investing in non-local non-S\&P stocks with high and low relative local ownership, respectively. Risk-adjusted monthly differential of 30 basis points translates into the annual differential of around $3.6 \%$, which, though substantially smaller than the raw return differential of $10 \%$, is still substantial. Another interpretation of the 30 basis point differential is that it is comparable to the risk-adjusted return resulting from zero-cost portfolio strategies on non-S\&P 500 stocks (26 basis points without controlling for the participating household portfolio locality and 30 basis points for the strategies involving only the households with above-median locality). In sum, mimicking what the locals do is about as good as being local (if you can't be local, join the locals), and betting that you may have found a winning investment that the local investors have overlooked is more often than not a losing proposition.

\section{IV.H. Something Closer}

Our choice of 250 miles as the cutoff between local and non-local investments was governed by an assumption that the distance of 250 miles is a plausible upper bound on the span of local information. As discussed earlier, this cutoff is admittedly arbitrary and it could be argued that it is on the conservative side. As a robustness check, in unreported analyses we replicated the basic analyses from Table V with the locality cutoff set at 100 kilometers (around 62 miles). 27

Changing the locality threshold has several implications. First, the breakdown into local and non-local portfolio shares changes from $31 \%$ vs. $69 \%$ to $20 \%$ vs. $80 \%$. ${ }^{28}$ Second, the results based on the 100 kilometer-cutoff are very consistent, and are even stronger by $30 \%$ to $50 \%$, which suggests that our choice of 250 miles as the cutoff indeed was conservative.

\footnotetext{
${ }^{27}$ A table with detailed results based on the 100-kilometer cutoff is available from the authors upon request.

${ }^{28}$ Moreover, the breakdown with respect to both locality and S\&P 500 status changes along the same lines: from $16 \%, 15 \%, 41 \%$, and $28 \%$ portfolio shares invested into local S\&P 500, local non-S\&P 500, non-local S\&P 500, and non-local non-S\&P 500 stocks at the 250 mile cutoff to the respective portfolio shares of $10 \%, 11 \%, 47 \%$, and $32 \%$ at the 100 kilometer cutoff.
} 
Finally, the 100-kilometer cutoff allows for some direct comparisons between the results pertaining to individual investors and those pertaining to mutual fund managers (Coval and Moskowitz, 2001). In terms of portfolio locality shares, the average fraction of the mutual fund portfolio that is local is only $7 \%$, whereas the average household portfolio share of local investment in our sample is $20 \%$. In terms of performance of local investments, Coval and Moskowitz (2001) find that the difference in raw returns from investing locally vs. non-locally is $2.7 \%$ over the one-year horizon (1.2\% difference in risk-adjusted returns). Our estimates, backed out from the unreported analyses using the 100-kilometer cutoff, suggest that the difference in raw returns from investing locally is $4.8 \%$ for individual investors $(1.7 \%$ difference in riskadjusted returns).

This result should be interpreted with due caution. It does not necessarily suggest that individual investors in some sense have outperformed the professional money managers. Rather, it suggests that there indeed is locally available value-relevant information to be discovered, and that the primary source of mutual fund managers' success along this dimension likely is their awareness of the existence of such information and their diligence in collecting it, rather than some particularly insightful and sophisticated way of interpreting it once it is available to them.

\section{Conclusion}

This study provides a detailed insight into the availability of asymmetric information in financial markets, particularly in the context of geography of investment by individual investors. Using a detailed data set on the investments 78,000 U.S. retail investors made through a large retail discount broker over the six-year period from 1991 to 1996, we find that individual investors exhibit local bias, that is, disproportionate preference for local stocks, to an even larger degree than U.S. mutual fund managers do (see Coval and Moskowitz, 1999).

As for the preference for local stocks, we sought to discern whether such local bias is primarily a result of the individual investors' ability to exploit asymmetric information or their inclination simply to invest into the companies they are familiar with (though not necessarily particularly informed about). We find remarkably robust evidence of superiority of individual investors' local investments relative to their non-local investments. This evidence is particularly 
strong where information asymmetries are likely to play the most pronounced role-among the non-local, less widely known stocks.

The significance of the results presented herein stretches beyond the concerns related to individual investors; it helps us refine our understanding of the professional managers ability to exploit local information (Coval and Moskowitz, 2001). Specifically, two very different groups of investors posted similar returns to locality (differential performance between local and nonlocal stocks). Thus, both individual households and professional money managers seem to have been able to process and exploit locally available information to earn excess returns.

\section{References}

Barber, Brad, and Terrance Odean, 2000, Trading is hazardous to your wealth: The common stock investment performance of individual investors, Journal of Finance 55, 773-806.

Barber, Brad, and Terrance Odean, 2001, Boys will be boys: Gender, overconfidence, and common stock investment, Quarterly Journal of Economics 116, 261-292.

Benartzi, Shlomo, 2001, Excessive extrapolation and the allocation of 401(k) accounts to company stock, Journal of Finance 56, 1747-64.

Bodie, Zvi, and Dwight B. Crane, 1997, Personal investing: Advice, theory, and evidence, Financial Analysts Journal, 13-23.

Brown, Stephen J., William N. Goetzmann, Roger G. Ibbotson, and Stephen A. Ross, 1992, Survivorship bias in performance studies, Review of Financial Studies 5, 553-580.

Cooper, Ian and Evi Kaplanis, 1994, Home bias in equity portfolios, inflation hedging, and international capital market equilibrium, Review of Financial Studies 7(1), 45-60.

Coval, Joshua D., and Tobias J. Moskowitz, 1999, Home bias at home: Local equity preference in domestic portfolios, Journal of Finance 54, 1-39.

Coval, Joshua D., and Tobias J. Moskowitz, 2001, The geography of investment: Informed trading and asset prices, Journal of Political Economy 109(4), 811-841.

Dhar, Ravi, and Alok Kumar, 2001, A non-random walk down the main street: Impact of price trends on trading decisions of individual investors, Working Paper, Department of Economics, Cornell University, December 2001.

Dhar, Ravi and Ning Zhu, 2002, Up close and personal: An individual Level Analysis of the Disposition Effect, Working Paper, Yale School of Management.

French, Kenneth R. and James M. Poterba, 1991, Investor diversification and international equity markets, American Economic Review 81, 222-226.

Gehrig, Thomas, 1993, An information based explanation of the domestic bias in international equity investment, Scandinavian Journal of Economics 95(1), 97-109. 
Goetzmann, William and Kumar, Alok, 2001, Equity portfolio diversification, NBER Working Paper 8686, December.

Grinblatt, Mark and Matti Keloharju, 2001, How distance, language, and culture influence stockholdings and trades, Journal of Finance 56(3), 1053-1073.

Hong, Dong and Alok Kumar, 2002, What induces noise trading around public announcement events, Working Paper, Department of Economics, Cornell University, February 2002

Huberman, Gur, 2001, Familiarity breeds investment, Review of Financial Studies 14(3), 659680 .

Kennickell, Arthur B. and Martha Starr-McCluer, 1994, Changes in family finances from 1989 to 1992: Evidence from the Survey of Consumer Finances, Federal Reserve Bulletin 80, 861882.

Kumar, Alok, 2002, Individual investor sentiment and comovement in small stock returns, Working Paper, Department of Economics, Cornell University, September 2002.

Liang, Nellie and Scott Weisbenner, 2002, Investor behavior and the purchase of company stock in 401(k) pans - The importance of plan design, NBER Working Paper No. 9131.

Tesar, Linda L. and Ingrid M. Werner, 1997, Home bias and high turnover, Journal of International Money and Finance 14, 467-492.

U.S. Census Bureau: Gazetteer Place and Zip Code Database.

Weisbenner, Scott, 2002, Do pension plans with participant choice teach households to hold more equity?, Journal of Pension Economics and Finance, forthcoming.

Zhu, Ning, 2002, The local bias of individual investors, Working Paper, Yale School of Management. 


\section{Table I: Summary Statistics of Household Income and 1991 Household Portfolios}

The sample consists of 31,828 households that held at least $\$ 1,000$ of stocks in their portfolio at the end of 1991. Households could report annual income in nine ranges $(0-15,15-20,20-30$, $30-40,40-50,50-75,75-100,100-125$, and $125+$ thousands of dollars). One eighth of the households did not provide income information. The income level for the households in the first eight categories was assumed to be the midpoint of the income range. Households that reported income greater than $\$ 125,000$ were assigned an income level of $\$ 250,000$ because calculations using the 1992 Survey of Consumer Finances suggest that the average household income in 1991 for households that had at least $\$ 125,000$ of income was $\$ 250,000$. Household portfolio distance measures were computed by value-weighting the distance measures across individual stocks in the portfolio according to their household portfolio equity position.

\begin{tabular}{|c|c|c|c|}
\hline Panel A: Income Statistics & Mean & Median & $\begin{array}{l}25^{\text {th }}-75^{\text {th }} \\
\text { Percentile }\end{array}$ \\
\hline Income $<\$ 50,000$ & $25 \%$ & & \\
\hline Income between $\$ 50,000$ and $\$ 100,000$ & $39 \%$ & & \\
\hline Income over $\$ 100,000$ & $23 \%$ & & \\
\hline Household did not report income & $13 \%$ & & \\
\hline $\begin{array}{l}\text { Income level in thousands } \\
\text { (conditional on reporting a range) }\end{array}$ & $\$ 88$ & $\$ 63$ & $\$ 45-\$ 113$ \\
\hline Panel B: Basic Portfolio Statistics & Mean & Median & $\begin{array}{l}25^{\text {th }}-75^{\text {th }} \\
\text { Percentile }\end{array}$ \\
\hline Stock portfolio value & $\$ 29,643$ & $\$ 11,201$ & $\$ 5,575-\$ 25,059$ \\
\hline Number of stocks in portfolio & 3.0 & 2 & $1-3$ \\
\hline Assets other than common stocks held & $38 \%$ & & \\
\hline $\begin{array}{l}\text { Ratio of other assets to total assets in portfolio } \\
\text { (conditional on holding other assets) }\end{array}$ & $35 \%$ & $29 \%$ & $11 \%-56 \%$ \\
\hline Panel C: Distance Portfolio Statistics & Mean & Median & $\begin{array}{l}25^{\text {th }}-75^{\text {th }} \\
\text { Percentile }\end{array}$ \\
\hline $\begin{array}{l}\text { Distance to portfolio } \\
\text { (miles) }\end{array}$ & 924 & 795 & $308-1,406$ \\
\hline Distance to market portfolio & 1,221 & 1,024 & $759-1,820$ \\
\hline $\begin{array}{l}\text { Distance to portfolio minus } \\
\text { distance to market portfolio }\end{array}$ & -297 & -247 & $-697-151$ \\
\hline $\begin{array}{l}\text { Percent of portfolio within } 250 \text { miles } \\
\text { (percent of the \# of stocks within } 250 \text { miles) }\end{array}$ & $30.7 \%$ & $0.0 \%$ & $0.0 \%-64.8 \%$ \\
\hline Percent of all firms within 250 miles & $12.6 \%$ & $5.7 \%$ & $3.8 \%-14.7 \%$ \\
\hline $\begin{array}{l}\text { Percent of portfolio within } 250 \text { miles minus } \\
\text { percent of all firms within } 250 \text { miles }\end{array}$ & $18.1 \%$ & $-0.9 \%$ & $-5.7 \%-47.6 \%$ \\
\hline
\end{tabular}

"Slightly less than one-half of the households $(15,458$ of 31,828$)$ invest in at least one firm that is headquartered within 250 miles. 
Table II: Composition of Household Portfolios by Locality, 1991

The average local and non-local portfolio share across 31,828 households with at least $\$ 1,000$ in stock holdings at the end of 1991 is reported. A stock is defined as "local" for a given household if the firm is headquartered within 250 miles of the household. The "If invested in Industry Portfolio" shares in column (2) represent the hypothetical locality breakdown wherein for each stock the measure of locality is the ratio of aggregate market capitalization of all local firms belonging to the same industry and aggregate market capitalization all firms nationwide belonging to the same industry, and all the individual stock measures are then aggregated according to the weights of the respective stocks in the household portfolio.

\begin{tabular}{|c|c|c|c|c|c|c|c|c|}
\hline & $\begin{array}{l}\text { If Portfolio } \\
\text { Invested in } \\
\text { Market } \\
\text { (1) }\end{array}$ & $\begin{array}{l}\text { If Invested } \\
\text { in Industry } \\
\text { Portfolio } \\
\text { (2) }\end{array}$ & $\begin{array}{c}\text { All } \\
\text { Households } \\
\mathbf{( 3 )} \\
\end{array}$ & $\begin{array}{c}\text { Exclude CA } \\
\text { Households } \\
\text { (4) }\end{array}$ & $\begin{array}{c}\text { CA } \\
\text { Households } \\
\text { (5) }\end{array}$ & $\begin{array}{c}\text { Portfolio } \\
\geq \$ 10,000 \\
\text { (6) }\end{array}$ & $\begin{array}{c}\text { Portfolio } \\
\geq \$ 50,000 \\
\text { (7) }\end{array}$ & $\begin{array}{c}\text { Fraction } \\
\text { Invest Only in } \\
\text { Category } \\
\text { (8) }\end{array}$ \\
\hline \multicolumn{9}{|l|}{ Panel A: Basic Breakdown } \\
\hline $\begin{array}{l}\text { Local } \\
\text { Non-Local }\end{array}$ & $\begin{array}{l}12.6 \% \\
87.4 \%\end{array}$ & $\begin{array}{l}13.4 \% \\
86.6 \%\end{array}$ & $\begin{array}{l}30.7 \% \\
69.3 \%\end{array}$ & $\begin{array}{l}30.3 \% \\
69.7 \%\end{array}$ & $\begin{array}{l}31.9 \% \\
68.1 \%\end{array}$ & $\begin{array}{l}30.2 \% \\
69.8 \%\end{array}$ & $\begin{array}{l}27.7 \% \\
72.3 \%\end{array}$ & $\begin{array}{l}17.3 \% \\
51.4 \%\end{array}$ \\
\hline All Stocks ${ }^{*}$ & $100 \%$ & $100 \%$ & $100 \%$ & $100 \%$ & $100 \%$ & $100 \%$ & $100 \%$ & \\
\hline \multicolumn{9}{|l|}{$\begin{array}{l}\text { Panel B: Breakdown with } \\
\text { Respect to S\&P 500 }\end{array}$} \\
\hline $\begin{array}{l}\text { Local (S\&P 500) } \\
\text { Local (Not S\&P 500) }\end{array}$ & $\begin{array}{l}9.3 \% \\
3.2 \%\end{array}$ & $\begin{array}{l}9.8 \% \\
3.6 \%\end{array}$ & $\begin{array}{l}16.0 \% \\
14.6 \%\end{array}$ & $\begin{array}{l}16.7 \% \\
13.6 \%\end{array}$ & $\begin{array}{l}14.3 \% \\
17.5 \%\end{array}$ & $\begin{array}{l}17.0 \% \\
13.2 \%\end{array}$ & $\begin{array}{l}16.5 \% \\
11.2 \%\end{array}$ & $\begin{array}{l}7.9 \% \\
7.7 \%\end{array}$ \\
\hline $\begin{array}{l}\text { Non-Local (S\&P 500) } \\
\text { Non-Local (Not S\&P 500) }\end{array}$ & $\begin{array}{l}61.4 \% \\
26.0 \%\end{array}$ & $\begin{array}{l}59.3 \% \\
27.3 \%\end{array}$ & $\begin{array}{l}41.1 \% \\
28.2 \%\end{array}$ & $\begin{array}{l}40.9 \% \\
28.8 \%\end{array}$ & $\begin{array}{l}41.6 \% \\
26.5 \%\end{array}$ & $\begin{array}{l}44.4 \% \\
25.3 \%\end{array}$ & $\begin{array}{l}48.0 \% \\
24.3 \%\end{array}$ & $\begin{array}{l}21.1 \% \\
15.4 \%\end{array}$ \\
\hline All Stocks ${ }^{*}$ & $100 \%$ & $100 \%$ & $100 \%$ & $100 \%$ & $100 \%$ & $100 \%$ & $100 \%$ & \\
\hline Number of Households & 31,828 & 31,828 & 31,828 & 23,358 & 8,470 & 17,198 & 3,773 & 31,828 \\
\hline
\end{tabular}

*Portfolio shares are rounded to one tenth of a percent. Thus, shares may not add up to $100 \%$ due to rounding error. 
Table III: Regression of Locality of Household's Portfolio upon Household and Portfolio Characteristics, 1991

The table presents regressions of household portfolio (HHP) locality measures on portfolio and household characteristics. The sample consists of 31,828 households with at least \$1,000 in stock holdings at the end of 1991. For those households that did not report income, $\log$ (income) was set to zero and the indicator variable "Did not report income" was set to one. Standard errors (shown in parentheses) allow for heteroskedasticity.

\begin{tabular}{|c|c|c|c|c|c|c|c|c|}
\hline \multirow[b]{2}{*}{ Log (Number of stocks in HHP) } & \multicolumn{2}{|c|}{$\begin{array}{c}\text { Average distance to } \\
\text { portfolio stocks (miles) }\end{array}$} & \multicolumn{2}{|c|}{$\begin{array}{c}\text { Average distance to } \\
\text { portfolio stocks (miles) less } \\
\text { distance to market }\end{array}$} & \multicolumn{2}{|c|}{$\begin{array}{l}\% \text { of portfolio value within } \\
250 \text { miles (local) }\end{array}$} & \multicolumn{2}{|c|}{$\begin{array}{l}\% \text { of portfolio local - } \\
\% \text { of market local }\end{array}$} \\
\hline & $\begin{array}{l}96.3^{* * *} \\
(6.0)\end{array}$ & $\begin{array}{l}110.9^{* * *} \\
(7.6)\end{array}$ & $\begin{array}{c}121.6^{* * *} \\
(5.8)\end{array}$ & $\begin{array}{l}110.9^{* * *} \\
(7.6)\end{array}$ & $\begin{array}{l}-6.4^{* * *} \\
(0.3)\end{array}$ & $\begin{array}{l}-6.6^{* * *} \\
(.4)\end{array}$ & $\begin{array}{l}-7.2^{* * *} \\
(0.3)\end{array}$ & $\begin{array}{l}-6.6^{* * *} \\
(0.4)\end{array}$ \\
\hline Log (Value of stocks in HHP) & $\begin{array}{l}-18.5^{* * *} \\
(3.8)\end{array}$ & $\begin{array}{l}-21.9^{* * *} \\
(4.8)\end{array}$ & $\begin{array}{l}-30.6^{* * *} \\
(3.7)\end{array}$ & $\begin{array}{l}-21.9^{* * *} \\
(4.8)\end{array}$ & $\begin{array}{l}1.5^{* * *} \\
(0.2)\end{array}$ & $\begin{array}{l}1.5^{* * *} \\
(0.3)\end{array}$ & $\begin{array}{l}2.0^{* * *} \\
(.2)\end{array}$ & $\begin{array}{l}1.5^{* * *} \\
(0.3)\end{array}$ \\
\hline Log (Household income) & $\begin{array}{l}-6.4 \\
(5.5)\end{array}$ & $\begin{array}{r}0.2 \\
(7.6)\end{array}$ & $\begin{array}{l}-19.4^{* * *} \\
(5.3)\end{array}$ & $\begin{array}{r}0.2 \\
(7.6)\end{array}$ & $\begin{array}{l}2.5^{* * *} \\
(0.3)\end{array}$ & $\begin{array}{r}0.5 \\
(0.4)\end{array}$ & $\begin{array}{l}1.4^{* * *} \\
(0.3)\end{array}$ & $\begin{array}{r}0.5 \\
(0.4)\end{array}$ \\
\hline Did not report income & $\begin{array}{r}22.0 \\
(25.7)\end{array}$ & $\begin{array}{r}42.1 \\
(35.6)\end{array}$ & $\begin{array}{l}-39.3 \\
(25.2)\end{array}$ & $\begin{array}{r}42.1 \\
(35.6)\end{array}$ & $\begin{array}{l}7.0^{* * *} \\
(1.5)^{-}\end{array}$ & $\begin{array}{l}-0.9 \\
(2.0)\end{array}$ & $\begin{array}{l}3.0^{* *} \\
(1.4)\end{array}$ & $\begin{array}{l}-0.9 \\
(2.0)\end{array}$ \\
\hline $\begin{array}{l}\text { Hold other assets } \\
\text { (besides stocks) }\end{array}$ & $\begin{array}{l}63.8^{* * *} \\
(8.1)^{2}\end{array}$ & $\begin{array}{l}55.1^{* * *} \\
(10.1)^{*}\end{array}$ & $\begin{array}{l}67.0^{* * *} \\
(7.9)\end{array}$ & $\begin{array}{l}55.1^{* * *} \\
(10.1)\end{array}$ & $\begin{array}{l}-3.9^{* * *} \\
(0.5)\end{array}$ & $\begin{array}{l}-3.3^{* * *} \\
(0.6)\end{array}$ & $\begin{array}{l}-3.7^{* * *} \\
(0.4)\end{array}$ & $\begin{array}{l}-3.3^{* * *} \\
(0.6)\end{array}$ \\
\hline Constant & $\begin{array}{c}1,036^{* * *} \\
(40)\end{array}$ & & $\begin{array}{l}-57.3 \\
(39.8)\end{array}$ & & $\begin{array}{l}12.8^{* * *} \\
(2.3)\end{array}$ & & $\begin{array}{r}0.8 \\
(2.3)\end{array}$ & \\
\hline $\begin{array}{l}\text { Zip code effects } \\
\mathrm{R}^{2}\end{array}$ & $\begin{array}{c}\text { No } \\
0.0136\end{array}$ & $\begin{array}{c}\text { Yes } \\
0.0163\end{array}$ & $\begin{array}{c}\text { No } \\
0.0199\end{array}$ & $\begin{array}{c}\text { Yes } \\
0.0163\end{array}$ & $\begin{array}{c}\text { No } \\
0.0186\end{array}$ & $\begin{array}{c}\text { Yes } \\
0.0175\end{array}$ & $\begin{array}{c}\text { No } \\
0.0207\end{array}$ & $\begin{array}{c}\text { Yes } \\
0.0175\end{array}$ \\
\hline Number of households & 31,828 & 31,828 & 31,828 & 31,828 & 31,828 & 31,828 & 31,828 & 31,828 \\
\hline
\end{tabular}

*** $,{ }^{* *},{ }^{*}$ Significance at the 1 percent, 5 percent, and 10 percent levels, respectively. 


\section{Table IV: Relation Between Firm Relative Local Ownership and Firm Characteristics}

Relative local ownership is defined as the fraction of stock ownership in the firm that is located within 250 miles of the firm less the fraction of total nation-wide household portfolio value that is located within 250 miles of the firm. Firm market value and the total number of employees are each expressed in logarithms. The sample is restricted to stocks owned by at least 5 households in the sample at the beginning of each year (end of January for 1991) and end of November 1996, and consists of seven pooled cross sections from 1991-November 1996. Standard errors (shown in parentheses) allow for heteroskedasticity as well as correlation across observations of the same firm over time. The standard errors for the median regression are based on 200 bootstrap replications.

\begin{tabular}{|c|c|c|c|c|c|c|}
\hline & \multicolumn{2}{|c|}{ All Firms } & \multicolumn{2}{|c|}{ S\&P 500 Firms } & \multicolumn{2}{|c|}{ Non-S\&P 500 Firms } \\
\hline & Mean & Median & Mean & Median & Mean & Median \\
\hline $\begin{array}{l}\text { Leverage } \\
\text { (Debt to Assets) }\end{array}$ & $\begin{array}{l}-6.7^{* * *} \\
(2.1)\end{array}$ & $\begin{array}{l}-5.0^{* * *} \\
(1.6)\end{array}$ & $\begin{array}{l}-0.8 \\
(8.1)\end{array}$ & $\begin{array}{r}0.7 \\
(4.0)\end{array}$ & $\begin{array}{l}-7.8^{* * *} \\
(2.1)\end{array}$ & $\begin{array}{l}-7.4^{* * *} \\
(1.6)\end{array}$ \\
\hline Market Value & $\begin{array}{l}-0.5 \\
(0.3)\end{array}$ & $\begin{array}{r}0.5^{*} \\
(0.3)\end{array}$ & $\begin{array}{l}-1.9^{*} \\
(1.1)\end{array}$ & $\begin{array}{r}0.2 \\
(0.6)\end{array}$ & $\begin{array}{l}-0.3 \\
(0.4)\end{array}$ & $\begin{array}{l}0.9^{* * *} \\
(0.3)\end{array}$ \\
\hline Market-to-Book Ratio & $\begin{array}{r}0.0 \\
(0.1)\end{array}$ & $\begin{array}{r}0.0 \\
(0.1)\end{array}$ & $\begin{array}{l}-0.4 \\
(1.0)\end{array}$ & $\begin{array}{l}-0.7^{*} \\
(0.4)\end{array}$ & $\begin{array}{r}0.0 \\
(0.1)\end{array}$ & $\begin{array}{r}0.1 \\
(0.1)\end{array}$ \\
\hline Number of Employees & ${ }^{1.1^{* * *}}$ & $\begin{array}{l}1.1^{* * * *} \\
(0.2)^{2}\end{array}$ & $\begin{array}{l}-0.6 \\
(0.9)\end{array}$ & $\begin{array}{l}-1.2^{* *} \\
(0.6)\end{array}$ & $\begin{array}{l}1.3^{* * *} \\
(0.3)\end{array}$ & $\begin{array}{l}1.4^{* * *} \\
(0.3)\end{array}$ \\
\hline S\&P 500 & $\begin{array}{l}-5.0^{* * *} \\
(1.3)\end{array}$ & $\begin{array}{l}-5.1^{* * *} \\
(0.8)\end{array}$ & & & & \\
\hline Tech. or Biotech. & $\begin{array}{l}-0.1 \\
(0.8)\end{array}$ & $\begin{array}{l}1.8^{* * *} \\
(0.6)\end{array}$ & $\begin{array}{l}-0.2 \\
(1.8)\end{array}$ & $\begin{array}{r}1.3 \\
(1.1)\end{array}$ & $\begin{array}{r}0.1 \\
(0.9)\end{array}$ & $\begin{array}{l}2.1^{* * *} \\
(0.8)\end{array}$ \\
\hline Return Past 1 Year & $\begin{array}{r}0.2 \\
(0.3)\end{array}$ & $\begin{array}{l}-0.3 \\
(0.3)\end{array}$ & $\begin{array}{r}1.5 \\
(1.1)\end{array}$ & $\begin{array}{r}0.1 \\
(1.5)\end{array}$ & $\begin{array}{r}0.1 \\
(0.3)\end{array}$ & $\begin{array}{l}-0.5 \\
(0.4)\end{array}$ \\
\hline Total Risk Past 1 Year & $\begin{array}{l}-5.8 \\
(4.1)\end{array}$ & $\begin{array}{l}-3.4 \\
(4.0)\end{array}$ & $\begin{array}{l}-12.6 \\
(19.9)\end{array}$ & $\begin{array}{r}13.6 \\
(17.1)\end{array}$ & $\begin{array}{l}-4.3 \\
(3.8)\end{array}$ & $\begin{array}{l}-1.5 \\
(3.7)\end{array}$ \\
\hline Year effects & Yes & Yes & Yes & Yes & Yes & Yes \\
\hline R-squared & 0.0088 & 0.0062 & 0.0190 & 0.0054 & 0.0093 & 0.0103 \\
\hline $\begin{array}{l}\text { Number of } \\
\text { Observations }\end{array}$ & 13,717 & 13,717 & 2,512 & 2,512 & 11,205 & 11,205 \\
\hline
\end{tabular}

${ }^{* * *},{ }^{* *},{ }^{*}$ Significance at the 1 percent, 5 percent, and 10 percent levels, respectively. 


\section{Table V: Relation between Household Portfolio Returns and Locality}

The sample consists of 31,828 households with at least $\$ 1,000$ in stock holdings at the end of 1991. A stock is "local" for a given household if headquartered within 250 miles of the household. Actual household returns (calculated based on monthly rebalancing of their portfolio) are calculated over the next year, next 3 years, and next 5 years and are expressed in percentages. This return is then related to the portfolio shares at the end of 1991:

$$
\begin{aligned}
& R_{t, t+k}^{H H P}=\beta_{L} \% L_{t}+\beta_{N L} \% N L_{t} \text { and } \\
& R_{t, t+k}^{H H P}=\beta_{L, S P} \% L_{S P, t}+\beta_{N L, S P} \% N L_{S P, t}+\beta_{L, N S P} \% L_{N S P, t}+\beta_{N L, N S P} \% N L_{N S P, t} .
\end{aligned}
$$

Similarly, the average excess monthly household return $\alpha$ (calculated from a four-factor model and expressed in basis points) is then related to the portfolio shares at the end of 1991:

$$
\begin{aligned}
& \alpha^{H H P}=\beta_{L} \% L+\beta_{N L} \% N L \text { and } \\
& \alpha^{H H P}=\beta_{L, S P} \% L_{S P}+\beta_{N L, S P} \% N L_{S P}+\beta_{L, N S P} \% L_{N S P}+\beta_{N L, N S P} \% N L_{N S P} .
\end{aligned}
$$

Standard errors (shown in parentheses) allow for heteroskedasticity. 
Table V (continued)

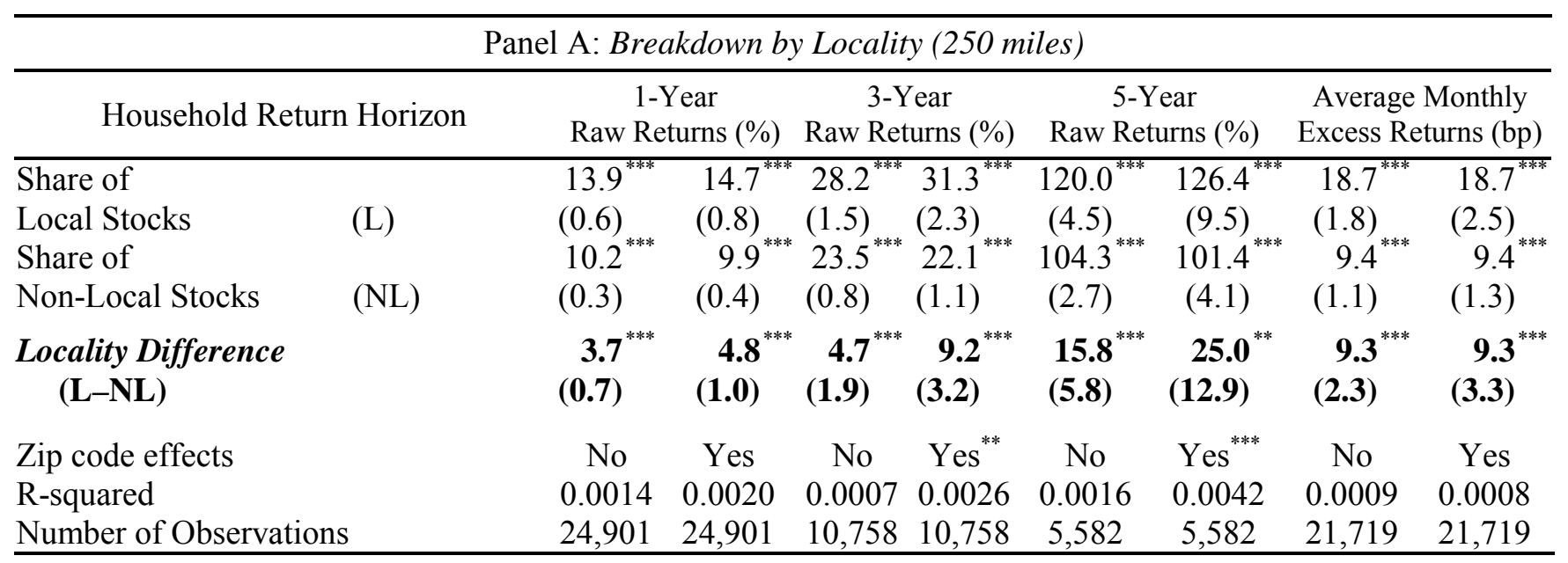

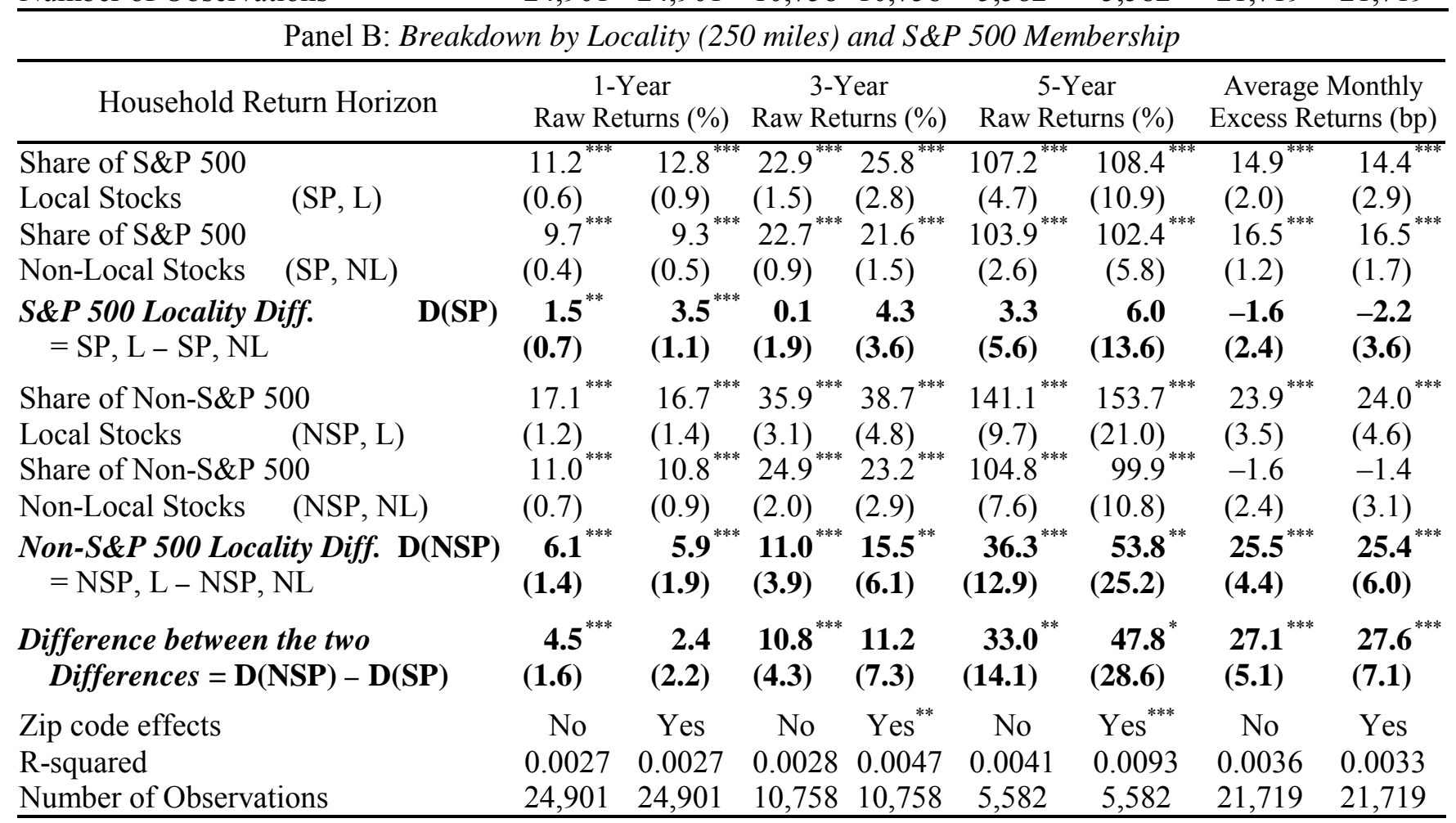

${ }^{* * *},{ }^{* *},{ }^{*}$ Significance at the 1 percent, 5 percent, and 10 percent levels, respectively. 


\section{Table VI: Robustness Checks on Relation between Household Portfolio Monthly Excess Returns and Locality}

The sample consists of 31,828 households with at least $\$ 1,000$ in stock holdings at the end of 1991. A stock is "local" for a given household if headquartered within 250 miles of the household. The average excess monthly household return $\alpha$ (calculated from a four-factor model and expressed in basis points) is then related to the portfolio shares at the end of 1991:

$$
\begin{aligned}
& \alpha^{H H P}=\beta_{L} \% L+\beta_{N L} \% N L \text { and } \\
& \alpha^{H H P}=\beta_{L, S P} \% L_{S P}+\beta_{N L, S P} \% N L_{S P}+\beta_{L, N S P} \% L_{N S P}+\beta_{N L, N S P} \% N L_{N S P} .
\end{aligned}
$$

Some specifications include the portfolio shares across 14 industry groups at the end of 1991. The table reports the differences in estimated coefficients. For the basic locality regression, the top panel, $\left(\beta_{L}-\beta_{N L}\right)$ is reported. For the regressions that interact locality with S\&P 500 membership, displayed in the bottom panel, $\left(\beta_{L, S P}-\beta_{N L, S P}\right),\left(\beta_{L, N S P}-\beta_{N L, N S P}\right)$, and $\left[\left(\beta_{L, N S P}-\right.\right.$ $\left.\left.\beta_{N L, N S P}\right)-\left(\beta_{L, S P}-\beta_{N L, S P}\right)\right]$ are reported. Standard errors (shown in parentheses) allow for

\begin{tabular}{|c|c|c|c|c|c|c|c|c|}
\hline \multicolumn{9}{|c|}{ Panel A: Breakdown by Locality (250 miles) } \\
\hline \multirow{2}{*}{$\begin{array}{l}\text { Sample } \\
\begin{array}{l}\text { Locality Difference } \\
(\mathrm{L}-\mathrm{NL})\end{array}\end{array}$} & \multicolumn{2}{|c|}{ Full Sample } & \multicolumn{2}{|c|}{$\begin{array}{l}\text { Exclude CA } \\
\text { households }\end{array}$} & \multicolumn{2}{|c|}{ CA households } & \multicolumn{2}{|c|}{$\begin{array}{l}\text { Exclude households } \\
\text { with retirement acct. }\end{array}$} \\
\hline & $\begin{array}{l}9.3^{* * *} \\
(2.3)\end{array}$ & $\begin{array}{l}5.9^{* * *} \\
(2.3)\end{array}$ & $\begin{array}{l}{ }^{*} 11.0 \\
(2.6)\end{array}$ & $\begin{array}{l}8.5^{* * *} \\
(2.6)\end{array}$ & $\begin{array}{r}4.6 \\
(4.7)\end{array}$ & $\begin{array}{l}-4.9 \\
(4.9)\end{array}$ & $\begin{array}{l}12.7^{* * *} \\
(\mathbf{3 . 3})\end{array}$ & $\begin{array}{l}7.2^{* *} \\
(3.2)\end{array}$ \\
\hline Portfolio Industry Shares included & & & No & Yes & & & No & \\
\hline & 0.0009 & & 0.0013 & 0.0316 & & & 0.0016 & 0.0374 \\
\hline Number of Observations & 21,719 & 21,719 & 16,059 & 16,059 & 5,660 & & 10,917 & 10,917 \\
\hline \multicolumn{9}{|c|}{ Panel B: Breakdown by Locality (250 miles) and S\&P 500 Membership } \\
\hline Sample & \multicolumn{2}{|c|}{ Full Sample } & \multicolumn{2}{|c|}{$\begin{array}{l}\text { Exclude CA } \\
\text { households }\end{array}$} & \multicolumn{2}{|c|}{ CA households } & \multicolumn{2}{|c|}{$\begin{array}{l}\text { Exclude households } \\
\text { with retirement acct. }\end{array}$} \\
\hline $\begin{array}{l}\text { S\&P } 500 \text { Locality Diff. } \\
\quad=\text { SP, L - SP, NL }\end{array}$ & $\begin{array}{l}-1.6 \\
(2.4)\end{array}$ & $\begin{array}{r}-3.2 \\
(2.3)\end{array}$ & $\begin{array}{l}5.5^{* * *} \\
(2.8)\end{array}$ & $\begin{array}{r}1.4 \\
(2.7)\end{array}$ & $\begin{array}{l}-23.7^{* * *} \\
(4.6)\end{array}$ & $\begin{array}{l}-22.3^{* * *} \\
(5.0)\end{array}$ & $\begin{array}{l}-1.8 \\
(3.4)\end{array}$ & $\begin{array}{c}-6.0 \\
(3.3)\end{array}$ \\
\hline $\begin{array}{l}\text { Non-S\&P } 500 \text { Locality Diff. D(NSP) } \\
\quad=\text { NSP, L - NSP, NL }\end{array}$ & $\begin{array}{l}25.5^{* * *} \\
(4.4)\end{array}$ & $\begin{array}{l}19.8 \\
(4.4)\end{array}$ & $\begin{array}{l}{ }^{*} 19.7^{* * *} \\
(5.1)\end{array}$ & $\begin{array}{l}19.6^{* * *} \\
(5.1)\end{array}$ & $\begin{array}{l}38.6^{* * *} \\
(8.9)\end{array}$ & $\begin{array}{l}17.0^{*} \\
(8.9)\end{array}$ & $\begin{array}{l}34.4^{* * *} \\
(6.4)\end{array}$ & $\begin{array}{l}27.0^{* * *} \\
(6.4)\end{array}$ \\
\hline $\begin{array}{l}\text { Difference between the two } \\
\text { Differences }=\mathrm{D}(\mathrm{NSP})-\mathrm{D}(\mathrm{SP})\end{array}$ & $\begin{array}{l}27.1^{* * *} \\
(\mathbf{5 . 1})\end{array}$ & $\begin{array}{l}23.0^{* * * *} \\
(5.1)\end{array}$ & $\begin{array}{l}14.2^{* *} \\
(5.9)\end{array}$ & $\begin{array}{l}18.1^{* * *} \\
(5.9)\end{array}$ & $\begin{array}{c}62.3^{* * *} \\
(10.1)\end{array}$ & $\begin{array}{c}39.2^{* * *} \\
(10.4)\end{array}$ & $\begin{array}{l}36.2^{* * *} \\
(7.3)\end{array}$ & $\begin{array}{l}21.0^{* * *} \\
(4.6)\end{array}$ \\
\hline o Industry Shares included & No & Yes & No & Yes & No & Yes & No & Yes \\
\hline & 0.0036 & 0.0353 & 0.0033 & 0.0350 & 0.0088 & 0.0428 & 0.0058 & 0.0422 \\
\hline Number of Observations & 21,719 & 21,719 & 16,059 & 16,059 & 5,660 & 5,660 & 10,917 & 10,917 \\
\hline
\end{tabular}
heteroskedasticity.

${ }^{* * *},{ }^{* *},{ }^{*}$ Significance at the 1 percent, 5 percent, and 10 percent levels, respectively. 


\section{Table VII: Relation Between Household Portfolio Returns and Locality, by Region}

The sample consists of 31,828 households with at least $\$ 1,000$ in stock holdings at the end of 1991. A stock is "local" for a given household if headquartered within 250 miles of the household. Actual household returns (calculated based on monthly rebalancing of their portfolio) are calculated over the next year. This return is related to the portfolio shares at the end of 1991:

$$
\begin{aligned}
& R_{t, t+k}^{H H P}=\beta_{L} \% L_{t}+\beta_{N L} \% N L_{t} \text { and } \\
& R_{t, t+k}^{H H P}=\beta_{L, S P} \% L_{S P, t}+\beta_{N L, S P} \% N L_{S P, t}+\beta_{L, N S P} \% L_{N S P, t}+\beta_{N L, N S P} \% N L_{N S P, t} .
\end{aligned}
$$

Similarly, the average excess monthly household return $\alpha$ (calculated from a four-factor model and expressed in basis points) is then related to the portfolio shares at the end of 1991:

$$
\begin{aligned}
& \alpha^{H H P}=\beta_{L} \% L+\beta_{N L} \% N L \text { and } \\
& \alpha^{H H P}=\beta_{L, S P} \% L_{S P}+\beta_{N L, S P} \% N L_{S P}+\beta_{L, N S P} \% L_{N S P}+\beta_{N L, N S P} \% N L_{N S P} .
\end{aligned}
$$

The table reports the differences in estimated coefficients for 1-year raw returns and average monthly excess returns across U.S. regions, as defined by the U.S. Bureau of the Census. For the

\begin{tabular}{|c|c|c|c|c|c|c|}
\hline \multirow[b]{2}{*}{ Region } & \multicolumn{3}{|c|}{$\begin{array}{c}1 \text {-Year } \\
\text { Raw Returns (\%) }\end{array}$} & \multicolumn{3}{|c|}{$\begin{array}{l}\text { Average Monthly } \\
\text { Excess Returns (bp) }\end{array}$} \\
\hline & $\left(\beta_{L}-\beta_{N L}\right)$ & $\left.{ }_{S S P}-\beta_{N L, N S P}\right)$ & \# HH & $\left(\beta_{L}-\beta_{N L}\right)$ & $\left(\beta_{L, N S P}-\beta_{N L, N S P}\right)$ & $\# \mathrm{HH}$ \\
\hline $\begin{array}{l}\text { New England } \\
\text { CT, ME, MA, NH, RI, VT }\end{array}$ & -1.6 & $15.4^{* *}$ & 1,150 & $24.9^{* *}$ & $35.7^{*}$ & 990 \\
\hline $\begin{array}{l}\text { Middle Atlantic } \\
\text { DE, DC, MD, NJ, NY, PA }\end{array}$ & -1.5 & $6.8^{* *}$ & 4,271 & $8.8^{*}$ & 0.9 & 3,748 \\
\hline $\begin{array}{l}\text { South Atlantic } \\
\text { FL, GA, NC, SC, VA, WV }\end{array}$ & $9.4^{* * *}$ & 6.1 & 2,748 & 0.3 & -26.0 & 2,390 \\
\hline $\begin{array}{l}\text { East North Central } \\
\text { IL, IN, OH, MI, WI }\end{array}$ & $6.0^{* * *}$ & 3.9 & 2,866 & $-12.8^{* *}$ & -7.3 & 2,478 \\
\hline $\begin{array}{l}\text { East South Central } \\
\text { AL, KY, MS, TN }\end{array}$ & $7.3^{* *}$ & $17.5^{* * *}$ & 623 & -11.0 & $49.8^{*}$ & 582 \\
\hline $\begin{array}{l}\text { West North Central } \\
\text { IA, KS, MN, MO, NE, ND, SD }\end{array}$ & -3.6 & -1.0 & 1,223 & $17.8^{*}$ & 16.2 & 1,067 \\
\hline $\begin{array}{l}\text { West South Central } \\
\text { AR, LA, OK, TX }\end{array}$ & $12.4^{* * *}$ & $17.9^{* * *}$ & 2,343 & $14.1^{*}$ & 12.8 & 2,027 \\
\hline $\begin{array}{l}\text { Mountain } \\
\text { AZ, CO, ID, MT, NV, NM, UT, WY }\end{array}$ & $7.7^{*}$ & 4.7 & 1,631 & -0.5 & 5.4 & 1,453 \\
\hline Pacific: CA, OR, WA & $4.5^{* * *}$ & $12.8^{* *}$ & 8,046 & $18.3^{* * *}$ & $52.9^{* * *}$ & 6,984 \\
\hline Pacific - exclude CA & -4.2 & -9.4 & 1,496 & $64.0^{* * *}$ & $84.0^{* * *}$ & 1,324 \\
\hline $\mathrm{CA}$ & $6.8^{* *}$ & $8.8^{* * *}$ & 6,550 & 4.6 & $38.6^{* * *}$ & 5,660 \\
\hline All Regions & $3.7^{* * *}$ & $6.1^{* * *}$ & 24,901 & $9.3^{* * *}$ & $25.5^{* * *}$ & 21,719 \\
\hline
\end{tabular}
basic locality regression, columns one and four, the difference $\left(\beta_{L}-\beta_{N L}\right)$ is reported. For the regressions that interact locality with S\&P 500 membership, columns two and five, the difference $\left(\beta_{L, N S P}-\beta_{N L, N S P}\right)$ is reported. Standard errors (not shown) allow for heteroskedasticity.

${ }^{* * *},{ }^{* *},{ }^{*}$ Significance at the 1 percent, 5 percent, and 10 percent levels, respectively. 


\section{Table VIII: Performance of Household Portfolio Aggregated by Locality}

At the beginning of each year (end of January for 1991), households are ranked based on the locality of their portfolio relative to the market portfolio (fraction of household portfolio within 250 miles less fraction of market portfolio within 250 miles) and then assigned to locality quartiles. Average household relative locality cutoffs across all years are: $-6.7 \%$ for quartile one, $-0.8 \%$ for the second quartile, and $45.8 \%$ for the third quartile. The return for each quartile represents the weighted return for all the households in that quartile (the weight is the value of each household's portfolio). Excess monthly returns are calculated from a four-factor model, which accounts for the market, size, book-to-market, and momentum effects. These four locality portfolios are rebalanced at the beginning of each year based on households' locality relative to the market portfolio. The sample period is $2 / 91$ through 12/96. Standard errors reported are Newey-West standard errors with autocorrelation up to three lags.

\begin{tabular}{lccccc}
\hline & \multicolumn{2}{c}{ Panel A: Raw Returns } & & \multicolumn{2}{c}{ Panel B: Excess Returns } \\
\cline { 2 - 3 } \cline { 5 - 6 } $\begin{array}{l}\text { Household by } \\
\text { Locality Quartile }\end{array}$ & $\begin{array}{c}\text { Average } \\
\text { Monthly Return }\end{array}$ & $\begin{array}{c}\text { Difference } \\
\text { Relative to } \\
\text { Top Quartile }\end{array}$ & & $\begin{array}{c}\text { Average Excess } \\
\text { Monthly Return }\end{array}$ & $\begin{array}{c}\text { Difference } \\
\text { Relative to } \\
\text { Top Quartile }\end{array}$ \\
\cline { 5 - 6 } $\begin{array}{l}\text { Quartile 1 } \\
\text { (Least Local) }\end{array}$ & $1.40 \%^{* * *}$ & $-0.190 \%^{*}$ & & $0.032 \%$ & $-0.176 \%$ \\
Quartile 2 & $(0.38)$ & $(0.101)$ & & $(0.125)$ & $(0.112)$ \\
Quartile 3 & $1.38^{* * *}$ & $-0.214^{*}$ & & 0.061 & -0.148 \\
Quartile 4 & $(0.34)$ & $(0.122)$ & & $(0.103)$ & $(0.126)$ \\
Most Local) & $1.35^{* * *}$ & $-0.245^{*}$ & & 0.032 & $-0.176^{*}$ \\
\hline
\end{tabular}

${ }^{* * *},{ }^{* *},{ }^{*}$ Significance at the 1 percent, 5 percent, and 10 percent levels, respectively. 


\section{Table IX: Regression of Monthly Portfolio Returns 2/91 - 12/96 (in percentage points), Local vs. Non-Local Investments}

The average raw return per month and the excess return per month (alpha) from various portfolios over the period 2/91 through 12/96 are expressed in percentage points. Excess monthly returns are calculated from a four-factor model, which accounts for the market, size, book-tomarket, and momentum effects. The loadings on each of the four factors are displayed above for the nine separate portfolios. Portfolio 1 (All Stocks, Local) is the return on local investments weighted across all household portfolios. Portfolio 2 (All Stocks, Non-Local) is the return on non-local investments weighted across all household portfolios. Portfolio 3 is the return on the zero-cost portfolio that is long local stocks (portfolio 1) and is short non-local stocks (portfolio 2), again weighted across all household portfolios. The middle three portfolios are defined analogously, but just focus on S\&P 500 stocks held by households. The right three portfolios are defined analogously, but just focus on non-S\&P 500 stocks held by households. A stock is "local" for a given household if headquartered within 250 miles of the household. Standard errors reported are Newey-West standard errors with autocorrelation up to three lags.

\begin{tabular}{|c|c|c|c|c|c|c|c|c|c|}
\hline & \multicolumn{3}{|c|}{ All Stocks } & \multicolumn{3}{|c|}{ S\&P 500 Stocks } & \multicolumn{3}{|c|}{ Non-S\&P 500 Stocks } \\
\hline & Local & Non-Local & Difference & Local & Non-Local & Difference & Local & Non-Local & Difference \\
\hline Market & $\begin{array}{l}1.12^{* * *} \\
(0.06)\end{array}$ & $\begin{array}{l}1.07^{* * *} \\
(0.04)\end{array}$ & $\begin{array}{r}0.05 \\
(0.03)\end{array}$ & $\begin{array}{l}1.04^{* * *} \\
(0.06)\end{array}$ & $\begin{array}{l}1.03^{* * *} \\
(0.04)\end{array}$ & $\begin{array}{r}0.01 \\
(0.03)\end{array}$ & $\begin{array}{l}1.25^{* * *} \\
(0.08)\end{array}$ & $\begin{array}{l}1.15^{* * *} \\
(0.06)\end{array}$ & $\begin{array}{c}0.10^{*} \\
(0.05)\end{array}$ \\
\hline Small minus big & $\begin{array}{c}0.24^{* * *} \\
(0.09)\end{array}$ & $\begin{array}{c}0.16^{* * *} \\
(0.06)\end{array}$ & $\begin{array}{c}0.09^{* * *} \\
(0.04)\end{array}$ & $\begin{array}{l}-0.17^{* *} \\
(0.08)\end{array}$ & $\begin{array}{l}-0.18^{* * *} \\
(0.06)\end{array}$ & $\begin{array}{r}0.01 \\
(0.03)\end{array}$ & $\begin{array}{l}0.82^{* * *} \\
(0.12)\end{array}$ & $\begin{array}{l}0.85^{* * *} \\
(0.08)\end{array}$ & $\begin{array}{l}-0.03 \\
(0.06)\end{array}$ \\
\hline High minus low & $\begin{array}{l}-0.10 \\
(0.07)\end{array}$ & $\begin{array}{l}-0.11^{*} \\
(0.05)\end{array}$ & $\begin{array}{r}0.00 \\
(0.03)\end{array}$ & $\begin{array}{l}-0.11 \\
(0.09)\end{array}$ & $\begin{array}{l}-0.11 \\
(0.07)\end{array}$ & $\begin{array}{r}0.00 \\
(0.04)\end{array}$ & $\begin{array}{l}-0.11 \\
(0.07)\end{array}$ & $\begin{array}{l}-0.11^{* *} \\
(0.05)\end{array}$ & $\begin{array}{r}0.00 \\
(0.05)\end{array}$ \\
\hline Up minus down & $\begin{array}{l}-0.09 \\
(0.06)\end{array}$ & $\begin{array}{l}-0.09^{* *} \\
(0.04)\end{array}$ & $\begin{array}{l}-0.00 \\
(0.03)\end{array}$ & $\begin{array}{l}-0.12^{*} \\
(0.06)\end{array}$ & $\begin{array}{l}-0.15^{* * *} \\
(0.05)\end{array}$ & $\begin{array}{r}0.03 \\
(0.03)\end{array}$ & $\begin{array}{l}-0.08 \\
(0.09)\end{array}$ & $\begin{array}{r}0.01 \\
(0.06)\end{array}$ & $\begin{array}{l}-0.09^{*} \\
(0.05)\end{array}$ \\
\hline $\begin{array}{l}\mathrm{p} \text {-value of } \\
\text { regression }\end{array}$ & $0.000^{* * *}$ & $0.000^{* * *}$ & $0.016^{* *}$ & $0.000^{* * *}$ & $0.000^{* * *}$ & 0.786 & $0.000^{* * *}$ & $0.000^{* * *}$ & 0.359 \\
\hline Alpha & $\begin{array}{r}0.16 \\
(0.14)\end{array}$ & $\begin{array}{r}0.04 \\
(0.10)\end{array}$ & $\begin{array}{c}0.12 \\
(\mathbf{0 . 0 7})\end{array}$ & $\begin{array}{c}0.30^{* *} \\
(0.15)\end{array}$ & $\begin{array}{l}0.22^{* *} \\
(0.11)\end{array}$ & $\begin{array}{r}0.08 \\
(\mathbf{0 . 0 7})\end{array}$ & $\begin{array}{l}-0.04 \\
(0.19)\end{array}$ & $\begin{array}{c}-0.30 \\
(0.16)\end{array}$ & $\begin{array}{c}0.26 \\
(0.09)\end{array}$ \\
\hline Raw Return & $\begin{array}{l}1.55^{\text {*** }} \\
(0.39)\end{array}$ & $\begin{array}{l}1.36^{* * *} \\
(0.35)\end{array}$ & $\begin{array}{l}0^{0.19}{ }^{* * * *} \\
(0.07)\end{array}$ & $\begin{array}{l}1.52^{* * *} \\
(0.35)\end{array}$ & $\begin{array}{l}1.40^{* * *} \\
(0.31)\end{array}$ & $\begin{array}{r}0.12^{*} \\
(0.07)\end{array}$ & $\begin{array}{l}1.58^{* * *} \\
(0.52)\end{array}$ & $\begin{array}{l}1.31^{* * *} \\
(0.49)\end{array}$ & $\begin{array}{c}0.27^{* * * *} \\
(\mathbf{0 . 0 9})\end{array}$ \\
\hline
\end{tabular}

*** ${ }^{* *},{ }^{*}$ Significance at the 1 percent, 5 percent, and 10 percent levels, respectively. 


\section{Table X: Average Monthly Returns of Zero-Cost Portfolios (Local minus Non-Local)2/91 - 12/96 (in percentage points),}

Formed with Respect to Household Portfolio Locality

The average raw return per month and the excess return per month (alpha) from various zero-cost portfolios over the period 2/91 through 12/96 are expressed in percentage points. Excess monthly returns are calculated from a four-factor model, which accounts for the market, size, book-tomarket, and momentum effects. The left panel focuses on all stocks held by households, and breaks those holdings into local and non-local investments. The return on the zero cost portfolio that is long local stocks and is short non-local stocks weighted across all household portfolios is displayed in the top row. This calculation is then repeated restricting the sample to households whose portfolio locality share is below the median (row 2) and above the median (row 3). At the beginning of each year (end of January for 1991), households are ranked based on the locality of their portfolio relative to the market portfolio (fraction of household portfolio within 250 miles less fraction of market portfolio within 250 miles). The average household relative locality median cutoff across all years is $-0.8 \%$ for the median. The three rows of the middle panel portfolio are defined analogously, but just focus on S\&P 500 stocks held by households. The three rows of the right panel portfolio are defined analogously, but just focus on non-S\&P 500 stocks held by households. A stock is "local" for a given household if headquartered within 250 miles of the household. Standard errors reported are Newey-West standard errors with autocorrelation up to three lags.

\begin{tabular}{|c|c|c|c|c|c|c|}
\hline \multirow[b]{3}{*}{ All households } & \multicolumn{2}{|c|}{$\begin{array}{c}\text { All } \\
\text { Stocks }\end{array}$} & \multicolumn{2}{|c|}{$\begin{array}{l}\text { S\&P } 500 \\
\text { Stocks }\end{array}$} & \multicolumn{2}{|c|}{$\begin{array}{c}\text { Non- S\&P } 500 \\
\text { Stocks }\end{array}$} \\
\hline & Raw Return & Alpha & Raw Return & Alpha & Raw Return & Alpha \\
\hline & $\begin{array}{c}0.19^{\text {*** }} \\
(0.07)\end{array}$ & $\begin{array}{c}0.12^{*} \\
(0.07)\end{array}$ & $\begin{array}{c}0.12^{*} \\
(0.07)\end{array}$ & $\begin{array}{r}0.08 \\
(0.07)\end{array}$ & $\begin{array}{c}0.27^{* * *} \\
(0.09)\end{array}$ & $\begin{array}{l}0.26^{* * *} \\
(0.09)\end{array}$ \\
\hline \multicolumn{7}{|l|}{ Households by Locality } \\
\hline Household Locality Below Median & $\begin{array}{r}0.01 \\
(0.10)\end{array}$ & $\begin{array}{l}-0.06 \\
(0.10)\end{array}$ & $\begin{array}{r}0.08 \\
(0.11)\end{array}$ & $\begin{array}{r}0.07 \\
(0.11)\end{array}$ & $\begin{array}{r}0.01 \\
(0.18)\end{array}$ & $\begin{array}{l}-0.01 \\
(0.18)\end{array}$ \\
\hline Household Locality Above Median & $\begin{array}{l}0.24^{* * *} \\
(0.08)\end{array}$ & $\begin{array}{c}0.15^{* *} \\
(0.07)\end{array}$ & $\begin{array}{l}0.14^{* *} \\
(0.06)\end{array}$ & $\begin{array}{r}0.10 \\
(0.07)\end{array}$ & $\begin{array}{l}0.38^{* * *} \\
(0.12)\end{array}$ & $\begin{array}{l}0.30^{* * *} \\
(0.11)\end{array}$ \\
\hline
\end{tabular}

${ }^{* * * *},{ }^{* *}{ }^{*}$ Significance at the 1 percent, 5 percent, and 10 percent levels, respectively. 
Table XI: Regression of Monthly Portfolio Returns 2/91 - 12/96 (in percentage points), Biggest Local vs. Other Local Investments

The average raw return per month and the excess return per month (alpha) from various portfolios over the period 2/91 through 12/96 are expressed in percentage points. Excess monthly returns are calculated from a four-factor model, which accounts for the market, size, book-tomarket, and momentum effects. The loadings on each of the four factors are displayed above for the nine separate portfolios. Portfolio 1 (Biggest Local Stock) is the return on the biggest local investment weighted across all household portfolios. Portfolio 2 (Other Local Stocks) is the return on local investments, other than the household's largest, weighted across all household portfolios. Portfolio 3 is the return on the zero-cost portfolio that is long the biggest local stock (portfolio 1) and is short the other local stocks (portfolio 2), again weighted across all household portfolios. The middle three portfolios are defined analogously, but just focus on S\&P 500 stocks held by households. The right three portfolios are defined analogously, but just focus on non-S\&P 500 stocks held by households. Biggest S\&P 500 Local Stock represents the household's biggest local investment if it happens to be a member of the S\&P 500, and Biggest Non-S\&P 500 Local Stock represents the household's biggest local investment if it happens to not be a member of the S\&P 500. A stock is "local" for a given household if headquartered within 250 miles of the household. Standard errors reported are Newey-West standard errors with autocorrelation up to three lags.

\begin{tabular}{|c|c|c|c|c|c|c|c|c|c|}
\hline & \multicolumn{3}{|c|}{ All Local Stocks } & \multicolumn{3}{|c|}{ S\&P 500 Local Stocks } & \multicolumn{3}{|c|}{ Non-S\&P 500 Local Stocks } \\
\hline & Biggest & Other & Difference & Biggest & Other & Difference & Biggest & Other & Difference \\
\hline Market & $\begin{array}{l}1.12^{* * *} \\
(0.07)\end{array}$ & $\begin{array}{l}1.14^{* * *} \\
(0.06)\end{array}$ & $\begin{array}{l}-0.02 \\
(0.02)\end{array}$ & $\begin{array}{l}1.02^{* * *} \\
(0.07)\end{array}$ & $\begin{array}{l}1.09^{* * *} \\
(0.06)\end{array}$ & $\begin{array}{l}-0.08^{* * *} \\
(0.03)\end{array}$ & $\begin{array}{l}1.26^{* * *} \\
(0.09)\end{array}$ & $\begin{array}{l}1.20^{* * *} \\
(0.08)\end{array}$ & $\begin{array}{r}0.06 \\
(0.04)\end{array}$ \\
\hline Small minus big & $\begin{array}{c}0.25^{\text {*** }} \\
(0.09)\end{array}$ & $\begin{array}{c}0.25^{* *} \\
(0.10)\end{array}$ & $\begin{array}{r}0.00 \\
(0.03)\end{array}$ & $\begin{array}{l}-0.16^{* *} \\
(0.07)\end{array}$ & $\begin{array}{l}-0.19^{* *} \\
(0.09)\end{array}$ & $\begin{array}{r}0.03 \\
(0.03)\end{array}$ & $\begin{array}{l}0.82^{* * *} \\
(0.12)\end{array}$ & $\begin{array}{c}0.87^{* * *} \\
(0.12)\end{array}$ & $\begin{array}{l}-0.05 \\
(0.04)\end{array}$ \\
\hline High minus low & $\begin{array}{l}-0.12 \\
(0.08)\end{array}$ & $\begin{array}{l}-0.05 \\
(0.08)\end{array}$ & $\begin{array}{l}-0.07^{* *} \\
(0.03)\end{array}$ & $\begin{array}{l}-0.11 \\
(0.09)\end{array}$ & $\begin{array}{l}-0.10 \\
(0.10)\end{array}$ & $\begin{array}{l}-0.01 \\
(0.04)\end{array}$ & $\begin{array}{l}-0.15^{*} \\
(0.08)\end{array}$ & $\begin{array}{r}0.01 \\
(0.06)\end{array}$ & $\begin{array}{l}-0.15^{* * *} \\
(0.05)\end{array}$ \\
\hline Up minus down & $\begin{array}{l}-0.07 \\
(0.06)\end{array}$ & $\begin{array}{l}-0.17^{* * *} \\
(0.05)\end{array}$ & $\begin{array}{c}0.10^{* * *} \\
(0.03)\end{array}$ & $\begin{array}{l}-0.08 \\
(0.07)\end{array}$ & $\begin{array}{l}-0.21^{* * *} \\
(0.07)\end{array}$ & $\begin{array}{l}0.12^{* * *} \\
(0.02)\end{array}$ & $\begin{array}{l}-0.07 \\
(0.10)\end{array}$ & $\begin{array}{l}-0.13^{*} \\
(0.08)\end{array}$ & $\begin{array}{r}0.06 \\
(0.05)\end{array}$ \\
\hline $\begin{array}{l}\mathrm{p} \text {-value of } \\
\text { regression }\end{array}$ & $0.000^{* * *}$ & $0.000^{* * *}$ & $0.000^{* *}$ & $0.000^{* * *}$ & $0.000^{* * *}$ & $0.000^{* * *}$ & $0.000^{* * *}$ & $0.000^{* * *}$ & $0.000^{* * *}$ \\
\hline Alpha & $\begin{array}{r}0.13 \\
(0.15)\end{array}$ & $\begin{array}{r}0.22^{*} \\
(0.12)\end{array}$ & $\begin{array}{l}-0.08 \\
(0.07)\end{array}$ & $\begin{array}{c}0.27^{*} \\
(0.15)\end{array}$ & $\begin{array}{c}0.39^{* * *} \\
(0.14)\end{array}$ & $\begin{array}{l}-0.11 \\
(0.08)\end{array}$ & $\begin{array}{l}-0.05 \\
(0.20)\end{array}$ & $\begin{array}{l}-0.01 \\
(0.17)\end{array}$ & $\begin{array}{l}-0.04 \\
(\mathbf{0 . 1 0})\end{array}$ \\
\hline Raw Return & $\begin{array}{l}1.53^{* * *} \\
(0.40)\end{array}$ & $\begin{array}{l}1.58^{* * *} \\
(0.38)\end{array}$ & $\begin{array}{l}-0.05 \\
(0.07)\end{array}$ & $\begin{array}{l}1.49^{* * *} \\
(0.35)\end{array}$ & $\begin{array}{c}1.58^{* * *} \\
(0.35)\end{array}$ & $\begin{array}{c}-\mathbf{0 . 0 8} \\
(\mathbf{0 . 0 7})\end{array}$ & $\begin{array}{l}1.58^{\text {*** }} \\
(0.53)\end{array}$ & $\begin{array}{l}1.58^{\text {*** }} \\
(0.50)\end{array}$ & $\begin{array}{r}0.00 \\
(0.10)\end{array}$ \\
\hline
\end{tabular}

${ }^{* * *},{ }^{* * *},{ }^{*}$ Significance at the 1 percent, 5 percent, and 10 percent levels, respectively. 


\section{Table XII: Regression of Monthly Portfolio Returns 2/91 - 12/96 (in percentage points), robustness to California}

The average raw return per month and the excess return per month (alpha) from various portfolios over the period 2/91 through 12/96 are expressed in percentage points. Excess monthly returns are calculated from a four-factor model, which accounts for the market, size, book-tomarket, and momentum effects. The loadings on each of the four factors are displayed above for the six separate portfolios. Portfolio 1 (Non-S\&P 500 Stocks, Local) is the return on non-S\&P 500 local investments weighted across all non-California household portfolios. Portfolio 2 (All NonS\&P 500, Non-Local) is the return on non-local, non-S\&P 500 investments weighted across all non-California household portfolios. Portfolio 3 is the return on the zero-cost portfolio that is long non-S\&P 500 local stocks (portfolio 1) and is short non-local stocks (portfolio 2), again weighted across all non-California household portfolios. The right three portfolios are defined analogously, but just focus on non-S\&P 500 stocks held by California households. A stock is "local" for a given household if headquartered within 250 miles of the household. Standard errors reported are Newey-West standard errors with autocorrelation up to three lags.

\begin{tabular}{|c|c|c|c|c|c|c|}
\hline & \multicolumn{3}{|c|}{ Exclude CA households, Non-S\&P 500 Stocks } & \multicolumn{3}{|c|}{ CA households, Non-S\&P 500 Stocks } \\
\hline & Local & Non-Local & Difference & Local & Non-Local & Difference \\
\hline Market & $\begin{array}{l}1.08^{* * *} \\
(0.06)\end{array}$ & $\begin{array}{l}1.16^{* * *} \\
(0.06)\end{array}$ & $\begin{array}{l}-0.09^{*} \\
(0.05)\end{array}$ & $\begin{array}{l}1.60^{* * *} \\
(0.19)\end{array}$ & $\begin{array}{c}1.08^{* * *} \\
(0.07)\end{array}$ & $\begin{array}{l}0.52^{* * *} \\
(0.17)\end{array}$ \\
\hline Small minus big & $\begin{array}{l}0.74^{* * *} \\
(0.07)\end{array}$ & $\begin{array}{l}0.84^{* * *} \\
(0.07)\end{array}$ & $\begin{array}{l}-0.09 \\
(0.07)\end{array}$ & $\begin{array}{c}0.99^{* * *} \\
(0.26)\end{array}$ & $\begin{array}{l}0.84^{* * *} \\
(0.08)\end{array}$ & $\begin{array}{r}0.15 \\
(0.20)\end{array}$ \\
\hline High minus low & $\begin{array}{l}-0.03 \\
(0.08)\end{array}$ & $\begin{array}{l}-0.08 \\
(0.05)\end{array}$ & $\begin{array}{r}0.04 \\
(0.07)\end{array}$ & $\begin{array}{l}-0.20 \\
(0.21)\end{array}$ & $\begin{array}{l}-0.18^{* *} \\
(0.05)\end{array}$ & $\begin{array}{l}-0.03 \\
(0.19)\end{array}$ \\
\hline Up minus down & $\begin{array}{l}-0.07 \\
(0.08)\end{array}$ & $\begin{array}{r}0.01 \\
(0.06)\end{array}$ & $\begin{array}{l}-0.08 \\
(0.07)\end{array}$ & $\begin{array}{l}-0.09 \\
(0.20)\end{array}$ & $\begin{array}{r}0.02 \\
(0.06)\end{array}$ & $\begin{array}{l}-0.11 \\
(0.16)\end{array}$ \\
\hline $\mathrm{p}$-value of regression & $0.000^{* * *}$ & $0.000^{* * *}$ & $0.007^{* * *}$ & $0.000^{* * *}$ & $0.000^{* * *}$ & $0.000^{* * *}$ \\
\hline Alpha & $\begin{array}{r}0.15 \\
(0.23)\end{array}$ & $\begin{array}{l}-0.32^{* *} \\
(0.15)\end{array}$ & $\begin{array}{c}0.48 \\
(0.25)\end{array}$ & $\begin{array}{l}-0.37 \\
(0.53)\end{array}$ & $\begin{array}{l}-0.24 \\
(0.19)\end{array}$ & $\begin{array}{l}-0.13 \\
(0.46)\end{array}$ \\
\hline Raw Return & $\begin{array}{l}1.64^{* * *} \\
(0.47)\end{array}$ & $\begin{array}{l}1.32^{* * *} \\
(0.48)\end{array}$ & $\begin{array}{c}0.32^{*} \\
(\mathbf{0 . 1 8})\end{array}$ & $\begin{array}{l}1.59^{* *} \\
(0.78)\end{array}$ & $\begin{array}{l}1.28^{* * *} \\
(0.51)\end{array}$ & $\begin{array}{r}0.30 \\
(0.42)\end{array}$ \\
\hline
\end{tabular}

${ }^{* * *},{ }^{* *},{ }^{*}$ Significance at the 1 percent, 5 percent, and 10 percent levels, respectively. 


\section{Table XIII: Relation between Household Portfolio Raw Returns and Locality Revisited (Relation Between Returns and Non-Local Share Interacted with RLO)}

The sample consists of 31,828 households with at least $\$ 1,000$ in stock holdings at the end of 1991. A stock is "local" for a given household if headquartered within 250 miles of the household. Relative local ownership is defined as the fraction of stock ownership in the firm that is located within 250 miles of the firm less the fraction of total nation-wide household portfolio value that is located within 250 miles of the firm. The median RLO cutoff is $10.0 \%$. On average, non-S\&P 500 non-local stocks constitute $28.2 \%$ of the value of a household's portfolio (14.2\% has high RLO, 14.0 has low RLO). Actual household returns, based on monthly rebalancing of their portfolio, are calculated over the next year, next 3 years, and next 5 years. This return is then related to the portfolio shares at the end of 1991:

$$
R_{t, t+k}^{H H P}=\beta_{1} \% L_{S P, t}+\beta_{2} \% N L_{S P, t}+\beta_{3} \% L_{N S P, t}+\beta_{4} \% N L_{N S P, H i g h R L O, t}+\beta_{5} \% N L_{N S P, L o w R L O, t} .
$$

Standard errors (shown in parentheses) allow for heteroskedasticity.

\begin{tabular}{|c|c|c|c|c|}
\hline & \multicolumn{3}{|c|}{ Raw Returns (Compounded) } & \multirow{2}{*}{$\begin{array}{l}\text { Average } \\
\text { Excess } \\
\text { Monthly } \\
\text { Returns }\end{array}$} \\
\hline & 1 Year & 3 Years & 5 Years & \\
\hline Share of S\&P 500 Local Stocks & $\begin{array}{l}11.2^{* * *} \\
(0.6)\end{array}$ & $\begin{array}{l}22.8^{* * *} \\
(1.5)\end{array}$ & $\begin{array}{l}107.2^{* * *} \\
(4.7)\end{array}$ & $\begin{array}{l}0.15^{* * *} \\
(0.02)\end{array}$ \\
\hline Share of S\&P 500 Non-Local Stocks & $\begin{array}{l}9.7^{* * *} \\
(0.4)\end{array}$ & $\begin{array}{l}22.7^{* * *} \\
(0.9)\end{array}$ & $\begin{array}{l}103.8^{* * *} \\
(2.6)\end{array}$ & $\begin{array}{l}0.16^{* * *} \\
(0.01)\end{array}$ \\
\hline Share of Non-S\&P 500 Local Stocks & $\begin{array}{l}17.1^{* * *} \\
(1.2)\end{array}$ & $\begin{array}{l}35.9^{* * *} \\
(3.1)\end{array}$ & $\begin{array}{l}141.2^{* * *} \\
(9.7)\end{array}$ & $\begin{array}{l}0.24^{* * *} \\
(0.04)\end{array}$ \\
\hline $\begin{array}{l}\text { Share of Non-S\&P } 500 \text { Non-Local Stocks } \\
\text { with High Relative Local Ownership (high RLO) }\end{array}$ & $\begin{array}{l}16.0^{* * *} \\
(1.0)\end{array}$ & $\begin{array}{l}28.8^{* * *} \\
(2.6)\end{array}$ & $\begin{array}{l}120.5^{* * *} \\
(9.6)\end{array}$ & $\begin{array}{l}0.12^{* * *} \\
(0.03)\end{array}$ \\
\hline $\begin{array}{l}\text { Share of Non-S\&P } 500 \text { Non-Local Stocks } \\
\text { with Low Relative Local Ownership (low RLO) }\end{array}$ & $\begin{array}{l}6.1^{* * *} \\
(1.2)\end{array}$ & $\begin{array}{l}21.1^{* * *} \\
(3.4)\end{array}$ & $\begin{array}{l}88.2^{* * *} \\
(13.4)\end{array}$ & $\begin{array}{l}-0.18^{* * *} \\
(0.04)\end{array}$ \\
\hline $\begin{array}{l}\text { Non-S\&P } 500 \text { Local minus } \\
\text { Non-S\&P } 500 \text { Non-Local (high RLO) }\end{array}$ & $\begin{array}{r}1.1 \\
(1.6)\end{array}$ & $\begin{array}{c}7.1^{*} \\
(4.1)\end{array}$ & $\begin{array}{r}20.7 \\
(14.1)\end{array}$ & $\begin{array}{c}0.12^{* *} \\
(0.05)\end{array}$ \\
\hline $\begin{array}{l}\text { Non-S\&P } 500 \text { Non-Local (high RLO) minus } \\
\text { Non-S\&P } 500 \text { Non-Local (low RLO) }\end{array}$ & $\begin{array}{l}10.0 \\
(1.7)\end{array}$ & $\begin{array}{r}7.8^{*} \\
(4.5)\end{array}$ & $\begin{array}{r}32.3^{*} \\
(17.7)\end{array}$ & $\begin{array}{c}0.30 \\
(\mathbf{0 . 0 5})\end{array}$ \\
\hline p-value: All Non-S\&P 500 Coefficients the same & 0.000 & 0.007 & 0.008 & 0.000 \\
\hline $\begin{array}{l}\text { R-squared } \\
\text { Number of Observations }\end{array}$ & $\begin{array}{l}0.0052 \\
24,901\end{array}$ & $\begin{array}{l}0.0033 \\
10,758\end{array}$ & $\begin{array}{c}0.0055 \\
5,582\end{array}$ & $\begin{array}{l}0.0061 \\
21,719\end{array}$ \\
\hline
\end{tabular}

${ }^{* * *},{ }^{* *},{ }^{*}$ Significance at the 1 percent, 5 percent, and 10 percent levels, respectively. 
Figure 1: Distribution of U.S. Publicly-Traded Firms (black) and Retail Investors (gray), 1991

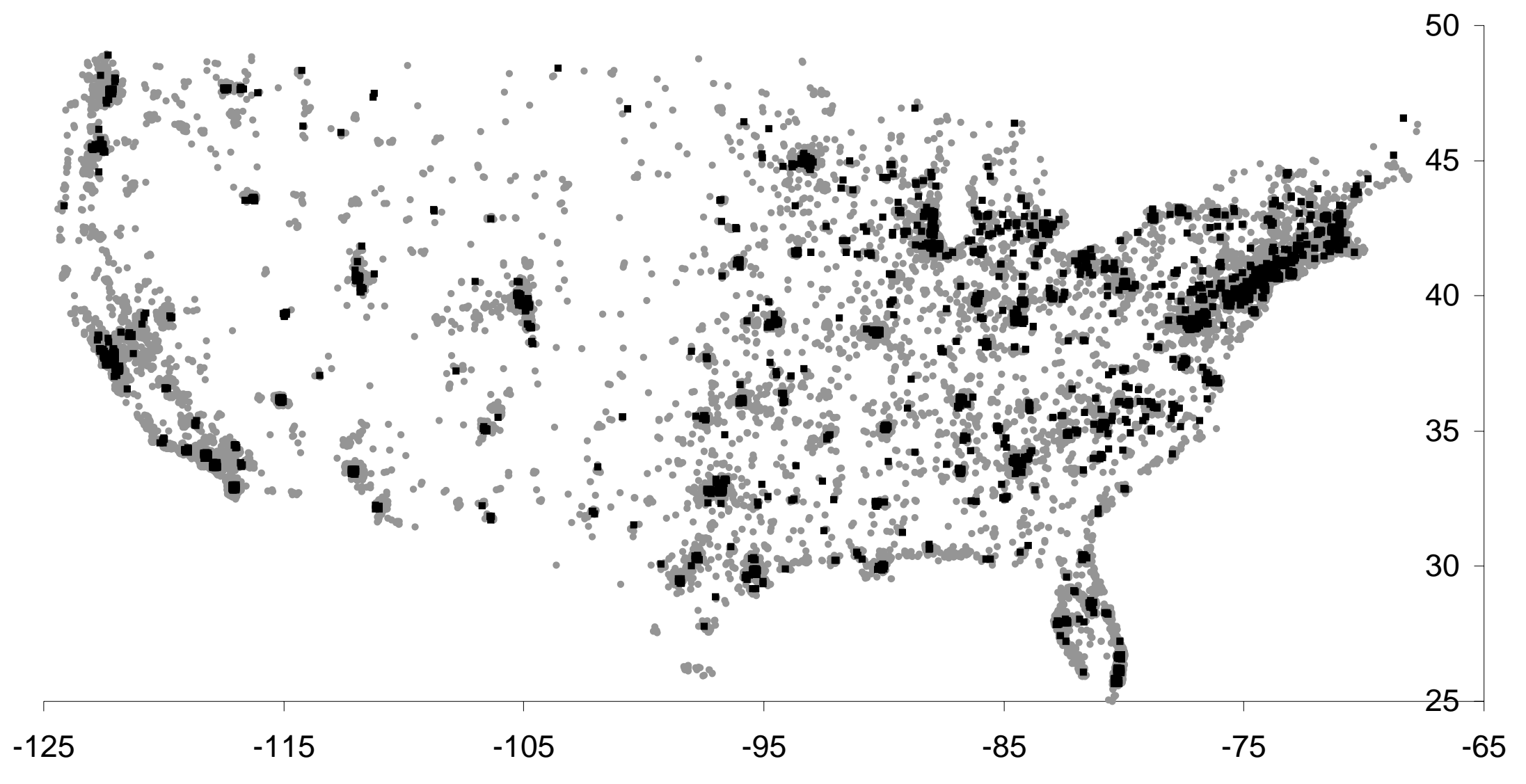

Sources: Compustat for firms' location and author's calculations for retail investors' location. 